\title{
CRIMEN ATROCISSIMUM: ENJUICIAMIENTO Y CASTIGO DE DELITOS ATROCES Y SU REPRESENTACIÓN EN LOS CUENTOS DE CANTERBURY
}

\author{
Miguel Martínez López \\ Universidad de Valencia
}

\section{RESUMEN}

Este trabajo analiza algunos de los principales textos jurídicos que regulan el enjuiciamiento y castigo de los crímenes más graves en el derecho medieval inglés y su plasmación en la obra literaria de Geoffrey Chaucer. Se estudian también algunos rasgos fundamentales del marco jurídico de estos crímenes entre los siglos XII y xIv; se ejemplifican las especialidades procesales de estos delitos mediante el análisis del juicio y ejecución de Hugh Le Despenser (1286-1326); y se explora el tema de la violación desde la perspectiva que ofrecen la vida y obra de Geoffrey Chaucer, con especial atención a Los cuentos de Canterbury. Este autor presenta en su obra un nuevo contexto en el que se avanza notablemente en la clarificación conceptual, terminológica y tipológica de la violación como crimen horrendo, merecedor de la pena de muerte.

PAlabras Clave: crímenes atroces, violación, tipología penal, Geoffrey Chaucer, Los cuentos de Canterbury.

\section{CRIMEN ATROCISSIMUM: PROSECUTION AND PUNISHMENT OF EXCEPTIONAL CRIMES AND ITS REPRESENTATION IN THE CANTERBURY TALES}

\section{Abstract}

This paper analyses some of the main legal texts that regulate the prosecution and punishment of exceptional crimes in medieval English law, and their transposition into Geoffrey Chaucer's literary work. Some fundamental features of the legal framework for the prosecution of these crimes between the 12th and the 14th centuries are also studied; the procedural singularities of this type of prosecution are explored through the analysis of the trial and execution of Hugh Le Despenser (1286-1326) and through the rape theme in Geoffrey Chaucer's works, with a particular focus on The Canterbury Tales. Chaucer writes in a new context, when conceptual, terminological and typological clarification of rape as a heinous crime against the person, a crime that carried the death penalty, was seeing significant progress.

Keywords: exceptional crimes, rape, types of penalties, Geoffrey Chaucer, The Canterbury Tales. 


\section{INTRODUCCIÓN}

Crimen atrocissimum, crimen exceptum, crimen atrox (vs. crimen levis), delicta atrociora, delicta atrocissima, crimen fori mixti... constituyen equivalentes aproximados de lo que en inglés contemporáneo se denomina hoy 'atrocious crimes' o 'exceptional crimes' y en español 'crímenes atroces': con estas expresiones latinas se ha venido haciendo referencia (desde la antigua Roma $^{1}$ hasta nuestros días ${ }^{2}$ ) a un conjunto ambiguo y cambiante de delitos, con variaciones geográficas y temporales, que podían incluir, en el periodo que nos ocupa (siglos XII a XIV) desde la alta traición, la brujería y el asesinato hasta el infanticidio, la falsificación de moneda y la sodomía. A Bonifacio VIII (1294-1303) se le atribuye la máxima de que a este tipo de delincuentes había que despacharlos «simple y expeditivamente, sin el ruido y las formas de abogados y jueces» ${ }^{3}$.

Hoy la ONU clasifica estos crímenes en tres grandes grupos definidos jurídicamente en el marco del derecho internacional público: genocidio, crímenes de lesa humanidad y crímenes de guerra. A diferencia de la variabilidad espaciotemporal de las definiciones en el Mundo Antiguo y la Edad Media ${ }^{4}$, las definiciones de los crímenes, a partir del siglo pasado, resultan algo más precisas 5 .

${ }^{1}$ M.T. Ciceronis, Pro Tito Annio Milone ad iudicem oratio (52 a.C.). Lovaina, Apud Vanlinthout et Vendenzendi, 1849, p. 93. Sobre derecho penal romano, véanse C. Ferrini, Diritto penale romano. Esposizione storica e dottrinale (1902). Roma, L'Erma di Bretschneider, 1976; RoBInson, O.F. The Criminal Law of Ancient Rome. Baltimore, John Hopkins UP, 2001.

2 ONU, Marco de Análisis para la Prevención de Crimenes Atroces, 2014; reimp. 2018. http://www.un.org/en/genocideprevention/documents/publications-and-resources/Genocide_Framework\%20of\%20Analysis-Spanish.pdf.

${ }^{3}$ P. Carus, History of the Devil. New York, Dover Pubs., 2008, p. 325. Véase también A. Masferrer, «La distinción entre delito y pecado en la tradición penal bajomedieval y moderna. Una propuesta revisionista de la historiografía espańola, europea y anglosajona». Anuario de Historia del Derecho Español, 87, 2017, p. 693-756.

${ }_{4}^{4}$ También en España encontramos estas expresiones latinas, estableciéndose su origen en el ius comune a partir del siglo XIII, de forma más o menos contemporánea respecto del derecho inglés. Vid. I. Ramos Vázquez, «La represión de los delitos atroces en el Derecho Castellano de la Edad Moderna». Revista de estudios histórico-jurídicos, n. ${ }^{\circ}$ 6, 2004, pp. 255-299, quien también explora la indeterminación del concepto de atrocidad y los delitos considerados atroces por el derecho castellano del Antiguo Régimen. También en España se ha concluido que del ius commune procede la distinción entre delicta atrocissima o atrociora, delicta gravia et delicta levia. Véase A. Masferrer, Tradición y reformismo en la codificación penal española. Hacia el ocaso de un mito. Materiales, apuntes, reflexiones para un nuevo enfoque metodológico e historiográfico del movimiento codificador europeo. Jaén, Universidad de Jaén, 2003, p. 121: «Los primeros (atrocissimus o atrociora) eran aquellos por los que se imponía la pena más grave que la simple muerte; gravia (o atrocia), los que tenían por consecuencia la pena de muerte natural o civil; y levia, los castigados con las demás penas».

5 Vid. Convención para la Prevención y la Sanción del Delito de Genocidio (1948), https:// www.un.org/en/genocideprevention/documents/Appeal-Ratification-Genocide-FactSheet-SP.PDF; los Convenios de Ginebra (1949) con sus Protocolos Adicionales (1977) https://www.icrc.org/es/document/los-convenios-de-ginebra-de-1949-y-sus-protocolos-adicionales y el Estatuto de Roma de la Corte Penal Internacional (1998), https://www.un.org/spanish/law/icc/statute/spanish/rome_statute(s).pdf, 
Resulta difícil abstraerse de esta perspectiva contemporánea al analizar los textos del pasado, pero es menester leer los textos, jurídicos y literarios, al menos en una primera aproximación, en sus propios términos. Este es el objetivo del presente trabajo: contextualizar primero la evolución del enjuiciamiento y castigo de crímenes muy graves en el Medioevo inglés, analizar uno de los castigos más severos documentados a través del caso Le Despenser y explorar el reflejo de este tema en la literatura del periodo mediante el estudio del tema de la violación en la biografía de Geoffrey Chaucer y en Los cuentos de Canterbury.

Estrechamente vinculado a esta expresión, crimen atrocissimum, surge en el periodo que nos ocupa el aforismo «in atrocissimus leviores conjecturae sufficiunt, et licet iudici iura transgredi». Sin aportar ninguna racionalidad taxonómica que ayude a la definición o catálogo de estos crímenes, este término revela una de sus caracte-

entre otros tratados. A continuación se transcribe la clasificación de la ONU, Marco de Análisis para la Prevención de Crimenes Atroces, 2014 (vid. nota n. ${ }^{\circ}$ 2):

I. Genocidio: Convención para la Prevención y la Sanción del Delito de Genocidio

Art. 2: En la presente Convención, se entiende por genocidio cualquiera de los actos mencionados a continuación, perpetrados con la intención de destruir, total o parcialmente, a un grupo nacional, étnico, racial, o religioso, como tal: a) Matanza de miembros del grupo; b) Lesión grave a la integridad física o mental de los miembros del grupo; c) Sometimiento intencional del grupo a condiciones de existencia que hayan de acarrear su destrucción física, total o parcial; d) Medidas destinadas a impedir los nacimientos en el seno del grupo; e) Traslado por fuerza de nińos del grupo a otro grupo.

II. Lesa humanidad: Estatuto de Roma, art. 7: A los efectos del presente Estatuto, se entenderá por «crimen de lesa humanidad» cualquiera de los actos siguientes cuando se cometa como parte de un ataque generalizado o sistemático contra una población civil y con conocimiento de dicho ataque:
a) Asesinato;
b) Exterminio;
c) Esclavitud;
d) Deportación o traslado forzoso de población; e) Encarcelación u otra privación grave de la libertad física en violación de normas fundamentales de derecho internacional;
f) Tortura;
g) Violación, esclavitud sexual, prostitución forzada, embarazo forzado, esterilización forzada o cualquier otra forma de violencia sexual de gravedad comparable;
h) Persecución de un grupo o colectividad con identidad propia fundada en motivos políticos, raciales, nacionales, étnicos, culturales, religiosos, de género [...], u otros motivos univer- salmente reconocidos como inaceptables con arreglo al derecho internacional, en conexión con cualquier acto mencionado en el presente párrafo o con cualquier crimen de la com- petencia de la Corte;
i) Desaparición forzada de personas;
j) El crimen de apartheid;
k) Otros actos inhumanos de carácter similar que causen intencionalmente grandes sufrimien- tos o atenten gravemente contra la integridad física o la salud mental o física.

III. Crímenes de guerra. Vid. ONU 2014: Marco de Análisis, pp. 28-32 (incluye depuración étnica).

2. A los efectos del párrafo 1:
a) Por «ataque contra una población civil» se entenderá una línea de conducta que implique la comisión múltiple de actos mencionados en el párrafo 1 contra una población civil, de conformidad con la política de un Estado o de una organización de cometer ese ataque o para promover esa política. 
rísticas esenciales: la evolución del peculiar enjuiciamiento de estos delitos, al permitir un sinnúmero de especialidades procesales y sancionadoras para la persecución de un catálogo de crímenes, considerados en cada momento singularmente atroces. Se trata de un proceso extraordinario, de plazos muy cortos (cuando no sumarísimo) y con ausencia de un buen número de garantías procesales de las que era habitualmente titular un acusado. Cuando se trata de crímenes atroces, resume el citado aforismo, los más leves indicios o conjeturas bastan para condenar, y el juez puede trasgredir la ley a su antojo. Aún en 1764, Cesare Beccaria -criminólogo, jurista, filósofo y político de la Ilustración- clamaba contra la cruel imbecilidad de este axioma, producto, a su parecer, del miedo ante crímenes atroces difíciles de probar, por lo que los jueces se imaginaban obligados a inaplicar las formalidades -hoy hablaríamos de garantías procesales- establecidas, convirtiendo el enjuiciamiento en una suerte de juego del que el azar y el engaño constituían elementos principales ${ }^{6}$. Este planteamiento derivaba de un intento desesperado de proteger la estabilidad de los monarcas y sus reinos, para intentar mantenerlos a salvo de conspiraciones e intentos de derrocamiento. Por tanto, la figura del delito atroz solía traer causa de lo que hoy denominaríamos como una utilización extrema del derecho penal para la prevención de delitos políticos.

También las sanciones, segundo elemento diferencial que analizaremos, constituían penas agravadas, que se ejecutaban en público de forma particularmente atroz, y que podían alcanzar también a descendientes o familiares. Otro aforismo, "make the punishment fit the crime», o teoría retributiva del castigo (proporcionalidad del hecho punible y la pena impuesta), justificaría en este periodo la condena y ejecución de penas verdaderamente atroces, en virtud de una peculiar aplicación del principio de proporcionalidad entre la infracción y la sanción, que vendría a ser una ley del talión de aplicabilidad agravada, pues el sadismo que presidía las ejecuciones no respondía necesariamente a actos idénticos o similares por parte del reo. Como puede apreciarse en la sentencia y ejecución de Hugh Le Despenser (12861326), que analizamos en el siguiente apartado, tal interpretación del aforismo poco tiene que ver con el racionalismo y el utilitarismo continental, que incluyen, ya en el siglo XVIII, en la idea de ajuste ( $f t$ t), el principio de proporcionalidad, con la ponderación de posibles circunstancias atenuantes y procurando siempre una solución de compromiso equilibrada entre la maldad del delito y el dolor del castigo, entre el daño causado y su posible compensación a través del dolor de la pena.

Respecto a las penas, si bien es imposible determinar con alguna exactitud o certidumbre el origen del concepto de castigo, al tratarse de una institución ya existente en las sociedades primitivas (o, más propiamente, jurídicamente poco desarrolladas), cabría decir que desde los propios albores de la historia, mucho se ha especulado, y se sigue especulando, sobre su posible definición, sin que se haya conseguido nunca un alto grado de consenso. A. Warren Stearns ${ }^{7}$ sugiere que la definición tra-

${ }^{6}$ C. Beccaria, Dei delitti e delle pene (1764). Livorno, Torchi di Glauco Massi, 1833, p. 61.

7 Sobre la definición y evolución del concepto de castigo, se resume aquí la posición de A.W. Stearns, «Evolution of punishment». Journal of Criminal Law and Criminology, vol. 27, n. ${ }^{\circ}$, 
dicional de castigo como «un mal que se inflige a un malhechor, en tanto que malhechor, en nombre y a discreción de la sociedad en su capacidad corporativa, de la que es miembro temporal o permanente» resulta insatisfactoria, porque, por ejemplo, excluye el castigo a animales y a prisioneros de guerra, a menudo capturados lejos de la sociedad a cargo del enjuiciamiento. El carácter naturalmente contagioso de la expresión emocional de los sentimientos de los individuos se transmite rápidamente a los grupos sociales; así, sostiene Warren Stearns ${ }^{8}$ que el control de los individuos por parte de las sociedades es análogo al que ejercen unos individuos sobre otros a su cargo, siendo probablemente las penas la expresión de la irritación social frente a individuos que transgreden los patrones de conducta establecidos para un determinado grupo. Tras la autocomplacencia, el miedo, la crueldad y la expiación, sobrevienen los castigos penales para justificar la universal propensión a castigar tan común en individuos y sociedades. Del mismo modo que el sentido de finalidad de comer es mantener la vida, pero la razón de comer es satisfacer el apetito, así la razón del castigo sería la defensa individual o social, sin excluir una reacción instintiva ante una acción o realidad irritante o molesta, aspecto este último que podría contribuir a explicar (junto con el elemento disuasorio) la extrema crueldad de los castigos penales de ciertos crímenes horrendos en algunos periodos de la historia.

Las sociedades prejurídicas ${ }^{9}$, generalmente reguladas por la costumbre, prestaban poca atención a las querellas entre individuos, que solían ajustar cuentas entre sí, por acuerdo o lucha. Por el contrario, cuando consideraban que una infracción amenazaba el bienestar del grupo, su reacción era muy distinta. En el año 621 a.C., Dracón de Tesalia codificó el derecho penal procurando quitar a los nobles la potestad de juzgar, condenar y ejecutar arbitrariamente, pasando la competencia del clan

1936, p. 219. [Mi traducción]. Otra aproximación más reciente a esta misma cuestión puede encontrarse en Lacy, N., State Punishment. Political Principles and Community Values. London, Routledge, 1988, pp. 16-27. En él argumenta detalladamente la extrema dificultad de una definición de partida, ya que el lenguaje aporta una 'textura abierta' a los conceptos, que hace que las palabras tengan un significado central bien establecido y una zona de penumbra sobre cuyos posibles significados existirán siempre discrepancias entre sujetos y según contextos. Propone como definición de partida la siguiente: "Castigo legal es cuando el Estado inflige a individuos que han infringido la ley -según estándares públicamente reconocidos y sin error o desviación respecto de los hechos o principios conocidos por el juzgador- por parte de una institución estatal lo que generalmente se considera como consecuencias desagradables».

8 A.W. STEarns, «Evolution of punishment», p. 220.

9 A.W. Stearns, «Evolution of punishment», pp. 220-221.Se sigue aquí la terminología y posición de A.W. Stearns, aunque no puede obviarse que la costumbre es fuente del derecho y que desde la existencia de los primeros humanos existía lenguaje para comunicarse y derecho para regular de algún modo sus relaciones. Michael Gagarin distingue entre sociedades prejurídicas, protojurídicas y plenamente jurídicas, aunque admite que es una terminología muy contingente; se refiere a las sociedades prejurídicas cuando no tienen mecanismos pacíficos de resolución de conflictos, públicos, formales y reconocidos. Véase M. Gagarin, Early Greek Law. Berkeley, University of California Press, 1986, p. 9. 
al Estado y estableciendo por escrito las normas de enjuiciamiento, un catálogo de delitos y sus correspondientes penas ${ }^{10}$.

Es práctica común entre los historiadores del derecho inglés datar sus orígenes a finales del periodo de dominio romano (siglo v) tras las invasiones de las tribus de origen germánico y escandinavo, cuyo derecho, menos conocido, se considera más o menos primitivo y, en todo caso, estrictamente local. Este periodo abarca desde las postrimerías del dominio romano hasta 1066.

Entre la conquista normanda y el siglo XIV, es menester destacar el reinado de Enrique II, cuando se establecen jueces ambulantes competentes para todos los delitos en todos los condados de Inglaterra. También del reinado de Enrique II proviene la curia regis, tribunales reales que aplicaban el derecho común a parcelas específicas: la primera de ellas estaba a cargo de la hacienda pública, 'Court of the Exchequer'; luego se creó la responsable de los asuntos de derecho civil -'Court of Common Pleas', verdadero tribunal a mbulante que acompañaba al rey en todos sus desplazamientos- y, por último, se creó el 'King's Bench', que conocía de las causas penales y de todas aquellas que afectaran directamente a la Corona.

Paradójicamente, el mayor grado de consenso entre los historiadores del derecho se encuentra en la datación del periodo formativo del derecho común a partir de la conquista normanda (1066), considerándose que dura hasta el advenimiento de los Tudor en 1485. Entonces Thomas More, cuya biografía, como se ha puesto frecuentemente de manifiesto, le convierte en el último gran autor medieval y primer gran humanista del Renacimiento en Inglaterra, tenía siete años; algo parecido sucede con la muerte de Geoffrey Chaucer en 1400, que se considera punto final de la Edad Media en las letras inglesas, a cargo del más 'moderno' de sus autores, último gran escritor en inglés medio; ambos, Chaucer y More, además de literatos, funcionarios, diplomáticos..., eran hombres de solidísima formación jurídica, que se formaron en las 'Inns of Court' de Londres y que representan dos puntos de referencia esenciales para la investigación de la evolución del derecho penal en Inglaterra. Por estas y otras razones, el marco temporal seleccionado para el análisis del reflejo de estos crímenes en la literatura inglesa se centra en las postrimerías del siglo XIV, cuando Chaucer escribe Los cuentos de Canterbury.

En el periodo que nos ocupa tiene lugar también una evolución relevante en el ámbito de la administración de justicia y específicamente en el derecho procesal inglés, que afecta directamente al objeto de nuestro estudio: la introducción progresiva de la figura del fiscal o acusador público. Si bien es fácil recorrer la historia de jueces y jurados en Inglaterra desde la alta Edad Media, la acusación pública no existe formalmente en Inglaterra hasta el periodo Tudor y aun entonces con sustantivas limitaciones en cuanto a su jurisdicción, que se limita al ámbito penal de

10 A Dracón se le atribuye la primera codificación de las leyes de la ciudad hacia el año 621 a.C. Durante sus años de legislador publicó el llamado Código Draconiano, que incluía penas muy severas para diferentes delitos -incluyendo las infracciones menores-. Por ejemplo, el robo de legumbres o verduras era castigado con la muerte. Sin embargo, es difícil saber si fue él quien instituyó tales castigos o simplemente reflejó en las leyes el derecho consuetudinario vigente en su época. 
los delitos atroces o muy graves. Es el 'Justice of the Peace' (JPs) el que sustituye, a partir del Tardomedioevo, al jurado instructor, testigo e instructor simultáneamente al que, por su proximidad geográfica, se le suponía conocimiento de los hechos o capacidad para informarse, configurando un jurado que hablaba más que escuchaba, que interrogaba y emitía veredictos con la misma naturalidad con la que se privaba con frecuencia al acusado de asistencia letrada, de acceso al texto de la denuncia y de turno de palabra, ni preliminar ni última. Recorrer los territorios de la memoria para trazar con documentable precisión las fases del nacimiento de la fiscalía en el derecho inglés no es cosa fácil (y puede que no sea siquiera viable), excediendo en todo caso las posibilidades de este estudio; como veremos más adelante, la persecución de delitos como la violación por parte del Estado, con independencia de la denuncia de particulares, supone un cambio normativo y práctico de consecuencias relevantes en el abordaje de delitos graves contra las personas y se gesta a finales del siglo XIv. Por una parte, existen casos documentados de separación de las figuras del testigo y el jurado ya en los primeros ańos del siglo XIII y, por otra, hasta la segunda mitad del siglo xv, sir John Fortescue se jactaba de la eficaz fusión de las funciones instructora y jurada en el proceso civil y penal inglés ${ }^{11}$. Lo más que puede aventurarse, según John Langbein, es que esta anomalía procesal, ya hacía tiempo superada en el continente, no podía sobrevivir al ocaso de la Edad Media en Inglaterra $^{12}$. En el siglo XVI, como los juicios de Moro y Raleigh pusieron de manifiesto, al menos para los denominados 'State Trials', casos extraordinarios que afectaban a la autoridad política, sí que es evidente que se nombraban fiscales de la Corona que se ocupaban de armar, formular y presentar la acusación.

${ }^{11} \mathrm{~J}$. Fortescue, De laudibus legum Angliae (1543). On the Laws and Governance of England. Edited by Shelly Lockwood. Cambridge, Cambridge University Press, 1997. Esta obra de Fortescue (c. 1394-1479) fue compuesta entre 1468 y 1471 y circuló en forma manuscrita durante la vida de su autor (Chief Justice of the King's Bench -Justicia Mayor del Reino- bajo el reinado de Enrique VI) pero no se publicó hasta 1543 , bajo el reinado de Enrique VIII y con un título ligeramente distinto. Mantenía Fortescue que el juicio por jurado era la forma de enjuiciamiento prevalente en Inglaterra desde el siglo XI. https://archive.org/stream/delaudibusleguma00fortuoft/delaudibusleguma00fortuoft_djvu.txt.

${ }^{12}$ J. Langbein, Prosecuting crime in the Renaissance: England, Germany and France. Cambridge, Harvard UP, 1974, pp. 118-122, citado por Th.A. Greene, «The Jury and the English Law of Homicide, 1200-1600». Michigan Law Review, 74, p. 489: «The jury ceased during the later Middle Ages to be a self- informing institution. While the process by which this occurred and the corollary emergence of the prosecution are largely hidden from our view, the later stages of prosecutorial development in the middle decades of the sixteenth century are more clear. The details of which we are aware suggest how the procedural changes resulted in changes in the law». 


\section{ENJUICIAMIENTO Y CASTIGO DE LOS CRÍMENES ATROCES EN LA INGLATERRA DEL SIGLO XIV: EL CASO DE HUGH LE DESPENSER, 1ST LORD DESPENSER (C. 1286-24 NOVEMBER 1326)}

Un ejemplo paradigmático de hasta dónde podía llegar el castigo de crímenes atroces, es el del proceso sumarísimo y ejecución de Hugh Le Despenser ${ }^{13}$, favorito del rey Eduardo II. Tras ser detenido en su huida con Baldock y Reading, y tras haber intentado sin éxito suicidarse por inanición, la mañana del 24 de noviembre de 1326, en la ciudad de Hereford, Hugh Despenser (c. 1286-24 noviembre 1326), probable pareja sentimental del rey Eduardo II, fue obligado a desnudarse y ponerse una túnica con su escudo nobiliario al revés y una corona de ortigas en la cabeza, y fue arrastrado al lugar de su juicio ${ }^{14}$. Isabella de Francia (reina consorte de Inglaterra por su matrimonio con Eduardo II) y el barón Roger Mortimer, su amante y aliado en la deposición del soberano, habían ponderado la conveniencia de llevar el juicio a Londres, pero el riesgo de muerte del prisionero, que le habría ahorrado el suplicio, les hizo anticipar el mismo, seguido de la ejecución de la sentencia, que finalmente se produjo a los ocho días de la detención, con un preso ya debilitado por su rechazo de alimento y bebida, en un intento desesperado por morir antes de que pudiera llevarse a cabo el juicio y la ejecución que de seguro le aguardaba tras el mismo.

Por el camino, la muchedumbre le marcó, unos mantienen que en la piel y otros que en la túnica, algunos versos del Magnificat («Él hace proezas con su brazo: dispersa a los soberbios de corazón, derriba del trono a los poderosos y enaltece a los humildes» Lucas 1, 54-57) y otros del Salmo 52 ("¿Por qué te jactas de la maldad, tú poderoso?» Salmos, 52:1). De esta guisa fue arrastrado por la ciudad entre pitos y tambores, acompañado por una muchedumbre que lo insultaba y le lanzaba cuantos

${ }_{13}$ El historiador Froissart dejó escrito que era un sodomita. También Adam Orleton, obispo de Winschester, formuló idéntica acusación contra Le Despenser y contra el propio rey Eduardo II, lo que justificaría la amputación y cremación peniana durante la ejecución del primero, como castigo por sodomía y herejía. Al invadir Inglaterra Isabella de Francia y Roger Mortimer en 1326, el obispo de Orleton dio un sermón, que consta en los Anales de la Abadía de Newenham, en el que denunció que Edward y Despenser, 'el rey y su marido', habían intentado huir a Gales. Mi resumen y traducción se basa en las siguientes fuentes: C. Sponsler, «The King's Boyfriend. Froissart's Political Theater of 1326", en G. Burger y S.F. Kruger, (eds.), Queering the Middle Ages, Medieval Cultures Series, 27, April, 2001, Minneapolis, University of Minnesota Press, p. 152; vid. también pp. 143157; N. Shopland, "The man with the upside-down arms», capítulo de Forbidden Lives LGTB. Histories from Wales. Bridgen, Seren Books, 2017, pp. 28-37. También sostiene la veracidad de esta relación íntima entre Eduardo II y Hugh Despenser Conor McCarthy, ed., Love, Sex and Marriage in the Middle Ages: A Sourcebook. Nueva York, Routledge, 2004, p. 156.

${ }^{14}$ Las fuentes consultadas para la elaboración de este apartado, además de Froissart, han sido las siguientes: I. MoRTIMER, The Greatest Traitor: The Life of Sir Roger Mortimer, Ruler of England: 1327-1330. London, Macmillan, 2013; G.A. Holmes, «Judgement on the Younger Despenser». The English Historical Review, vol. 70, n. ${ }^{\circ} 275$, pp. 261-267; D. Westerhof, «Deconstructing identities on the scaffold: the execution of Hugh Despenser the Younger, 1326». Journal of Medieval History, vol. 33, n. ${ }^{\circ} 1,2017$, pp. 87-106. 
objetos caían en sus manos. El espectáculo de su proceso y ejecución estaba diseñado para conseguir varios objetivos simultáneamente: maximizar la humillación del reo; optimizar el carácter potencialmente disuasorio de la pública ejecución de la pena; simbolizar la retirada de su rango y privilegios; finalmente, declarar la vergüenza pública de su familia y su linaje, que con la emasculación y posterior aniquilación dejaban de existir. De hecho, tras su muerte, su mujer fue encarcelada y sus hijas solteras obligadas a ingresar en conventos, tras la incautación de todos sus bienes ${ }^{15}$.

La vista tuvo lugar en la plaza del mercado, parte de la cual aún puede visitarse hoy; presidía muy probablemente sir William Trussel y también formaban parte del tribunal Henry, conde de Lancaster y Leicester, el conde de Kent, Thomas Wake, Jean de Hainault y Roger de Mortimer. Es posible que la reina Isabella estuviera también presente, pero son a menudo tan poco fiables las fuentes, particularmente en estos detalles, especialmente las Crónicas de Froissart ${ }^{16}$ y los Annales Paulini ${ }^{17}$, que resulta aventurado afirmar con rotundidad este extremo. Parece sumamente improbable que, caso de estar presente, tomara parte activa en el juicio. $\mathrm{Al}$ acusado no se le permitió intervenir en defensa propia, aunque, de habérsele concedido la palabra, tampoco parece probable que hubiera podido hacer uso de ella, debido a la extrema deshidratación que padecía. Trussel procedió a la lectura pública de los cargos, acordados previamente por el tribunal; algunos de ellos se correspondían con la realidad, eran públicos y notorios, otros solo parcialmente y de modo indiciario y otros nada tenían que ver con ella, pero entre todos ellos constituyen un ejemplo paradigmático de la sumarísima fase de instrucción de estos delitos atroces. El pliego de cargo, compuesto de cuatro largos documentos, incluía los nombres de todos aquellos contra quienes Hugh Despenser había delinquido, con

15 Este resumen, tanto de la acusación como de la ejecución, está basado en las siguientes fuentes: la versión original en francés medio (que no reproducimos por su extensión) y que puede consultarse en G.A. Holmes, "Judgment on the Younger Despenser 1326». The English Historical Review, vol. Lxx, n. ${ }^{\circ} 275,1$ April 1955, pp. 264-267. De los cuatro manuscritos que incluyen esta información, Holmes reproduce el A., por ser el que considera más fiable y mejor conservado (A. Durham, Dean and Chapter, loc. I, n. ${ }^{\circ} 35$ ), aunque también anota las diferencias principales con los otros tres. Una versión en lengua inglesa es la siguiente: Literae Cantuarienses. The Letter Books of the Monastery of Christ Church, V3: Canterbury (1889), ed. por J. Bridgstocke Sheppard. Cambridge, Cambridge University Press, 2012. Puede consultarse en línea (aunque con algunos defectos de transcripción) en https://archive.org/stream/literaecantuari00shepgoog/literaecantuari00shepgoog djvu.txt. J. Froissart (c. 1337-c. 1405), Chronicles of England, France, Spain and adjoining countries from the latter part of the reign of Edward II to the coronation of Henry IV. 2 vols. Trad. Thomas Johnes. London, Henry G. Bohn, 1857, p. 13. https://archive.org/stream/chroniclesengla00curngoog?r ef=ol\#page/n9/mode/2up; Annales Paulini 1307-1341. Stubbs, William, ed., Chronicles of the Reigns of Edward I and Edward II. London, Longman \& Co. (Rolls Series, n. $\left.{ }^{\circ} 76\right), 2$ vols., 1882-1883. Ian Mortimer, The Greatest Traitor: The Life of Sir Roger Mortimer, Ruler of England: 1327-1330. London, Macmillan, 2013, p. 160.

${ }^{16}$ J. Froissart (c. 1337-c. 1405), Chronicles of England, France, Spain..., p. 13. https:// archive.org/stream/chroniclesengla00 curngoog? ref=ol\#page/n9/mode/2up.

${ }_{17}$ Annales Paulini 1307-1341. Stubbs, William, ed., Chronicles of the Reigns of Edward I and Edward II. London, Longman \& Co. (Rolls Series, n. ${ }^{\circ}$ 76), 2 vols., 1882-1883. 
las habituales mezclas de hechos ciertos junto a especulaciones nunca demostradas, y contenía la imputación de un gran número de delitos:

Hugh le Despenser, in the parliament of our lord King Edward who now is, held at Westminster in the fifteenth year of his reign [August 1321], by investigation of the prelates, earls and barons and all the community of the realm, it was found to be well-known that your father and you, Hugh, were traitors and enemies of the realm, for which cause, by the assent and the command of our lord the king and all the baronage, your father and you, Hugh, were exiled from the realm never to return, which was done by the assent and permission of our lord the king and all the baronage and all those who were duly summoned to full parliament.

Against which judgement and exile, your father and you, Hugh, returned to the realm and were found at court without authorisation. And you, Hugh, in returning to the realm, feloniously robbed two dromonds of their goods to the value of $£ 60.000$ sterling, to the great dishonour of the king and the realm, and to the great peril of the merchants who often visit foreign countries. After this felony done by you, Hugh, you approached our lord the king and made him ride in arms against the peers of the realm and others of his faithful liegemen, to destroy and disinherit them contrary to Magna Carta and the Ordinances, and so riding in force and in arms, seizing royal power, you, Hugh, and your father and your adherents feloniously robbed the good men of the realm. With Andrew Harclay and other traitors, your adherents, you had the good earl of Hereford and Sir William Sully and Sir Roger Burghfield feloniously and maliciously murdered.

You took the good earl of Lancaster, who was the cousin-german of our lord the king and his brothers and uncle of the very noble king of France and his sister my lady the queen of England, and had him falsely imprisoned and robbed, and in his own hall in his castle, by your royal power which you had seized from our lord the king, had him judged by a false record contrary to law and reason and Magna Carta and also without response, and you had him martyred and murdered by hard and piteous death. And this wickedness and tyranny done to such an exalted person could not sate you of spilling the blood of Christians, and also on this same day, to further torment my said lord, before his vanquished eyes, you had his barons and knights condemned to death by drawing and hanging. By this false record contrary to law and reason, you shamefully had them hanged without mercy: Sir Warin Lisle, Sir William Tuchet, Sir Thomas Mauduit, Sir Henry Bradbourne, Sir William Cheney, Sir William Fitzwilliam the younger. At York, my lord Clifford, my lord Mowbray, Sir Jocelyn Deyville. At Canterbury, the lord Badlesmere and Sir Bartholomew Ashburnham. At London, Sir Henry Tyes. At Windsor, Sir Francis Aldenham. At Gloucester, the lord Giffard and Sir Roger Elmbridge. At Bristol, Sir Henry Wilington and Sir Henry Montfort. At Winchelsea, Sir Thomas Culpepper.

Many other magnates you had sent to hard prison, to murder them without cause for covetousness of their lands, such as the lord Mortimer and Mortimer the uncle and the lord Berkeley and Sir Hugh Audley the father and son, and the children of Hereford who were the nephews of our lord the king, and great ladies, wives of these lords, and their children, you kept in prison and orphaned. And after the deaths of their barons, you pursued widowed ladies such as my lady Baret, and as a tyrant you had her beaten by your mercenaries and shamefully had her arms and legs broken against the order of chivalry and contrary to law and reason, by 
which the good lady is forever more driven mad and lost. And many other such people who should have been ladies of great honour, you made follow the court on foot in great poverty, without pity and without mercy, and every day they were held in such great ignominy that God by his mercy sent our good and gracious lady and her son [Isabella and Edward III] and the good men who have come in their company to the land, by which the realm is delivered.

Hugh, after this destruction of our noble liege lord [Lancaster] and of other men of the realm done falsely, shamefully and treacherously, you, Hugh, and your father and Robert Baldock, who between you treacherously embraced royal power, had our lord the king and his people led to Scotland to the enemies, where you, by your treacherous conduct, lost more than 20.000 of his [Edward II's] people who died piteously by your default, to the great dishonour and damage of our lord the king and of all his people, without gaining advantage. After returning, you, Hugh, your father, and Robert Baldock, falsely and treacherously counselled our lord the king to leave my lady the queen in peril of her person in the priory of Tynemouth in Northumberland. You had our lord the king led in flight to Blackhow Moor, where his enemies of Scotland by your treacherous conduct surprised him, to the great dishonour and damage of the king and his people. And in such great misfortune and peril of her person, my lady who was your liege lady, by your treacherous deed might have been lost, to the perpetual dishonour and damage of the king and his realm, if God had not sent her deliverance by sea, thereby rescuing her from danger to her life and saving her honour, in such great grief of heart and body that no good lady of her estate and nobility should have at any time.

Hugh, neither this treason nor cruelty could suffice for you, but by the royal power which you had seized from our lord the king, you destroyed the privileges of Holy Church. The prelates Hereford, Lincoln, Ely, Norwich, you feloniously robbed of their goods inside Holy Church, and outside, you carried off their horses and their plate and their baggage, and made them go on foot. And their lands and their possessions you seized by force, against law and reason. It did not only suffice for you to make war on the ministers of Holy Church, but also you plundered it, as a false Christian, renegade and traitor against God himself. And because you knew that God made miracles by my good lord [Lancaster] whom you murdered so cruelly against the law without cause, you, Hugh, as a false Christian, sent armed men into Holy Church and had the doors of monasteries shut down and closed so that no-one was bold enough to enter the Church and worship God or his saints, for which merit and in defiance of you, God made divine gifts and miracles.

After this wickedness, you falsely and treacherously counselled our lord the king, to the disinheritance of his crown and his heirs, to give to your father, who was false and a traitor, the earldom of Winchester, and the earldom of Carlisle [Cardoile] to Andrew Harclay, who was a notorious traitor and criminal, and to you, Hugh, the land of Canteruaure [?], and other lands which belong to the crown. And also, Hugh, you, your father and Robert Baldock had my lady the queen ousted from her lands, which were given and assigned to her by our lord the king, and set her on her journey [to France in March 1325] meanly, against the dignity of her highness and of her estate. As a false and disloyal traitor, you daily abetted and procured discord between our lord the king and herself, by your complete royal power. And, Hugh, when my lady the queen and her son, by the command and assent of our lord the king, crossed the sea to save the land of Gascony, which was at point of being lost, by your treacherous counsel you sent over the sea a large sum of money 
to certain evil men, your adherents, to destroy my lady and her son, who was the rightful heir of the kingdom, and to prevent their return to this country, which would have been to their damage and their destruction, if you had succeeded in doing this [i.e., bribing people to murder Isabella and her son].

Hugh, your father and Robert Baldock and the other false traitors, your adherents, travelled around the kingdom by land and by sea, assuming royal power, making great and small people by constraint, promise and assure you that they would maintain you in your false quarrels against all people, regardless of the fact that such confederations were false and treacherous and against the bond and estate of the king and his crown. By your royal power you had them put in arduous prison, such as Sir Henry Beaumont, who did not want to swear that they would assent to your wickedness. And when you, Hugh, and the other false traitors, your adherents knew that my lady and her son were returning to this land, you made our lord the king, by your treacherous counsel, remove himself from them, and led him out of the kingdom in great peril of his person. And to the great dishonour of himself and of his people, you feloniously took the treasure of the realm and the great seal with you ${ }^{18}$.

Una vez terminada la relación de cargos, Trussel pasó, sin más trámite, a la lectura de la sentencia:

${ }_{18}$ Versión inglesa de K. Warner, «The Charges Against Hugh Despenser The Younger, November 1326", accesible en http://edwardthesecond.blogspot.com/2009/04/charges-against-hughdespenser-younger.html. Esta autora parte del original en francés medio reproducido por G.A. HoLMES, "Judgment on the Younger Despenser 1326». The English Historical Review, vol. LXx, n. ${ }^{\circ} 275$, 1 April 1955, pp. 264-267. De los cuatro manuscritos que los incluyen, Holmes utiliza el A, por ser el que considera más fiable y mejor conservado (A. Durham, Dean and Chapter, loc. I, n, ${ }^{\circ}$ 35). De K. Warner, véase también Edward II and Hugh Despenser the Younger: Downfall of a King's Favourite. Barnsley, Pen and Sword, 2018. Los textos del pliego de cargo y la sentencia están resumidos y traducidos por mí, a partir de estas dos fuentes principales (en francés medio y en inglés): volver del destierro sin permiso del Parlamento; piratería; tráfico de influencias; levantarse en armas contra los nobles del reino con intención de quitarles la vida y apoderarse de sus herencias; el asesinato del earl of Hereford, William de Sully, Roger de Berefield, y otros; encarcelar al earl of Lancaster y organizar su muerte asumiendo prerrogativas reales; ejecutar a diecisiete barones y caballeros del reino, incautándose de sus bienes; enviar a prisión a Roger de Mortimer y a su tío, conspirando para asesinarlos y apropiarse de sus tierra, a lord Berkeley, Hugh Audley senior y Hugh Audley junior, los niños del earl of Hereford, sus esposas y familiares, y a lady Baret; respecto de esta última se le acusaba también de romperle los brazos y las piernas hasta que se volvió loca; incitar al rey Eduardo a la guerra contra los escoceses, poniendo de este modo en grave peligro el reino; abandonar a la reina Isabella en el convento de Tynemouth obligándola a efectuar un peligroso viaje por mar cuando las fuerzas escocesas avanzaron hacia dicho priorato; despojar a varios obispos de sus iglesias; desheredar al rey; confiscar tierras de la reina, incluso las correspondientes a su dote; comportarse cruel y deshonrosamente con la reina, dańando su señorío y nobleza; evitar que el rey Eduardo viajara a Francia, con el resultado de pérdida de territorios; exportar capitales a Francia con el encargo de que mataran a la reina y a su hijo o, al menos, evitaran a toda costa que volvieran a Inglaterra; interponerse maliciosamente entre el rey y la reina para provocar su desacuerdo; otorgar favores y tierras a sus seguidores; abusar del poder real para encarcelar a todos los que, como Henry Beaumont, no le prestaban juramento de fidelidad; persuadir al rey para que abandone el reino y, contra legem, hacerle llevar con él el tesoro del reino y el gran sello. 
Hugh, as a traitor you are found, and as such are judged by all the good people of the realm, great and small, rich and poor. By common assent you are found as a thief and a criminal, and for this you will be hanged. And because you are found a traitor, you will be drawn and quartered, and [the pieces of your body] sent throughout the realm. And because you were exiled by our lord the king and by common assent and returned to the court without authorisation, you will be beheaded. And because you were always disloyal and procured discord between our lord the king and our very honourable lady the queen, and between other people of the realm, you will be disembowelled, and then they will be burnt. Withdraw, you traitor, tyrant, renegade; go to take your own justice, traitor, evil man, criminal! ${ }^{19}$.

Poco puede decirse con certeza del lugar exacto en que se llevó a cabo la ejecución, pues distintos autores la sitúan en lugares diversos, desde extramuros hasta el mismo lugar en que se había desarrollado el simulacro de juicio, el mercado. Sea como fuere, sería arrastrado por la ciudad sobre una estructura de madera que garantizase la llegada consciente al lugar del tormento. Durante este camino los reos solían recibir los insultos y golpes de la muchedumbre asistente, a la que no bastaba la contemplación de tan inhumano castigo, sino que exigía aprovechar la ocasión para poder desatar su rabia y su violencia impunemente. En este periodo sufriría, probablemente, una descarga de adrenalina y una severa hipertensión, consecuencias del estrés y la anticipación de lo inminente del tormento ${ }^{20}$, y desde el punto de vista de las heridas físicas, se ha sugerido que el reo solía sufrir laceraciones, hemorragias y desgarros internos; Hugh fue primero colgado hasta que el estrangulamiento le dejó

19 Versión inglesa de K. WARner, «The Charges Against Hugh Despenser The Younger, November 1326", accesible en http://edwardthesecond.blogspot.com/2009/04/charges-against-hughdespenser-younger.html. Mi traducción: «Hugh [nótese la privación de tratamiento nobiliario; ni lord Despenser, ni sir Hugh, sino simplemente Hugh, al haber perdido por sus obras el derecho al tratamiento propio de su rango, sustituyéndose por el que estaba al uso para los criminales de la plebe], has sido juzgado y condenado como traidor por haber amenazado a toda la buena gente del reino, grandes y pequeños, cuyo común acuerdo os tiene por ladrón. Por ser un ladrón, serás colgado; por ser un traidor serás desmembrado en cuatro partes, siendo distribuidas estas por el reino. Por prevalecer sobre nuestro señor el rey, volviendo del exilio sin su permiso, serás decapitado. Por haber intrigado, interponiéndoos entre el rey y la reina y otros nobles, serás destripado y tus entrañas serán quemadas; id a encontrar vuestro destino, traidor, tirano y renegado; id a recibir vuestra propia justicia, traidor, malvado y criminal».

${ }^{20}$ M.A. Picardo Reyes, Anatomía de la Tortura. Protocolo para la Documentación Psicosocial de la Tortura en el marco del Sistema Interamericano de Derechos Humanos. PDPT-SIDH. Iztapalapa, Universidad Autónoma Metropolitana de Méjico, 2003, p. 71. http://www.corteidh.or.cr/ tablas/r26107.pdf. "De acuerdo con Selye, esto provoca en el individuo dos tipos de respuesta: de afrontamiento o de huida (fight or flight, en inglés). Consecuentemente, el organismo se prepara para luchar o huir. Es así a que se produce un aumento del ritmo cardíaco, del ritmo respiratorio, de la presión sanguínea, se dilatan las pupilas, se tensan los músculos, se produce una vasoconstricción periférica, aumenta la glucemia, se libera adrenalina, noradrenalina, glucocorticoides, etc.». Vid. también el resumen de Jules Frusher de varias fuentes ya citadas, junto con algunos elementos plausibles de carácter más especulativo: J. Frusher, Hanging, Drawing and Quartering: the Anatomy of an Execution, http://www.ladydespensersscribery.com/2008/07/03/hanging-drawing-and-quartering-the-anatomy-of-an-execution/. 
semiinconsciente; luego le soltaron, como era costumbre, para evitar la muerte por asfixia, probablemente le abofetearon y ducharon con agua fría para reanimarlo; en esta fase solían producirse espasmos y las consecuencias de la ausencia de control de esfínteres, de la que quizá se librara en su caso por su voluntaria deshidratación y ayuno; a continuación, lo ataron a una escalera que, una vez levantada, recibía otra en paralelo con el torturador que empezaba por extirpar los genitales (pena no específicamente contemplada en la sentencia, como analizaremos con más detalle más adelante, aunque sí incluida por Froissart en sus Chronicles $^{21}$ ), seguía con la extracción de intestinos y corazón, todos los cuales eran lanzados al fuego. Si no había tenido la fortuna de perder el conocimiento o incluso haber muerto, la pérdida masiva de sangre y el shock hipovolémico resultado de las mutilaciones hacían sumamente probable su fallecimiento en este punto del sádico tormento. Para finalizar, se le bajó de la escalera, se le decapitó y descuartizó, remitiendo la cabeza en una pica a Londres para su exposición en London Bridge (al igual que ocurriera con Tomás Moro y tantos otros), y sus miembros a Bristol, York, Dover y Newcastle. Previamente al traslado se trataban los restos con una solución de salmuera y alquitrán para preservar el mayor tiempo posible su apariencia y evitar, en el caso de la cabeza, que las aves carroñeras se acercaran, dando al traste con ese postrer gesto cruel de disuasión. Mientras la multitud contemplaba eufórica el macabro espectáculo, varias fuentes señalan que la reina Isabella y Mortimer festejaban sin muestras de pérdida de apetito ante tan sangriento espectáculo ${ }^{22}$.

Arrastrar a un ser humano, castrarlo, destriparlo, decapitarlo y descuartizarlo son «manifestaciones de un ensañamiento que, al tiempo que pretende conservar una tradición» que se plasma en el ordenamiento inglés como 'Statutory penalty' en 1352, tras la aprobación por el Parlamento de la Treason Act de 1351 (aunque se venía practicando a lo largo de todo el siglo XIII en Inglaterra, desde su instauración por Enrique III), sirve también, según el historiador Ángel Rodríguez Sánchez, «al principio de consolidar el horror social que se consigue aplicando la irracional relación entre dimensión del delito y pena aplicada ${ }^{23}$. Los crímenes considerados atroces requerían de castigos igual o, preferiblemente, mucho más atroces, para garantizar el orden establecido y explotar al máximo su potencial efecto disuasorio.

${ }^{21}$ «[...] private parts cut off because he was a heretic and guilty of unnatural practices»; la amputación genital se justifica por la herejía y por las prácticas contra naturam; probablemente, es una referencia a su relación homosexual con el rey, que, en el pliego de cargos, aparece eufemísticamente descrita en el cargo n. ${ }^{\circ}$ 19. Vid. Froissart, p. 13.

${ }^{22}$ Los detalles de la ejecución están tomados del ya citado Ian Mortimer, The Greatest Traitor: The Life of Sir Roger Mortimer, Ruler of England: 1327-1330. London, Macmillan, 2013, p. 160. J. Frusher resume varias fuentes secundarias ya citadas (especialmente Westerhof y Mortimer) en http://www.ladydespensersscribery.com/2008/06/25/execution-day-november-24th-1326/.

${ }^{23}$ Á. Rodríguez SánCHEZ, «La soga y el fuego. La pena de muerte en Espańa siglos XVI y xviI». Cuadernos de Historia Moderna de la Universidad Complutense, n. ${ }^{\circ}$ 15, 1994, pp. 13-39. 


\section{G. CHAUCER Y EL DELITO DE VIOLACIÓN: LOS CUENTOS DE CANTERBURYY EL ESTATUTO SOBRE VIOLACIONES DE 1382}

De entre las dinámicas reclasificaciones tipológicas de los crímenes atroces, y con todas las reservas que resultan de lo planteado en las páginas anteriores, sin duda la violación de una virgen (rape solo se refería a la penetración del órgano sexual masculino en el femenino) -como la que describe Chaucer al inicio de El cuento de la comadre de Bath-y la sodomía (que englobaba el resto de conductas, heterosexuales y homosexuales) formaban parte, junto con la traición, asesinato, etc., del tipo más grave de delito durante la mayor parte de la Edad Media y el Renacimiento en Inglaterra, pero existieron importantes variaciones a lo largo del tiempo en su enjuiciamiento, penas y jurisprudencia. Hugh Despenser probablemente fue castrado y desorbitado por las reiteradas acusaciones de sodomía, si bien, como se ha dicho, no constaba expresamente en el literal de la sentencia ni en el pliego de cargos; Eduardo II había otorgado amplios poderes a sus dos favoritos (primero a Piers Gaveston y luego a Hugh Despenser) y la ciudadanía, como hemos visto más arriba, estaba convencida de que además eran amantes ('el rey y su marido') y que tal circunstancia había sido clave en la caída del monarca, quien, sin embargo, por su condición real, fue tratado con respeto tras el arresto, en abierto contraste con la terrible suerte de Hugh Despenser, ya analizada en el capítulo anterior. Paul Doherty ha dedicado parte de una de sus obras a intentar demostrar la teoría de que, además de su presunta sodomía, Hugh Le Despenser violó a la reina Isabella, todo lo cual explicaría también la emasculación y desorbitación que relatan algunas fuentes, sin que existan evidencias suficientes para afirmarlo ${ }^{24}$. También explicaría la ambigua y quizá eufemística formulación del cargo de "comportarse cruel y deshonrosamente con la reina, dañando su señorío y nobleza». Podría referirse al documentado abandono (y, para algunos, intento de asesinato) de la reina Isabella por parte del rey Eduardo II, consecuencia plausible de su relación con Despenser, a una agresión sexual directa, a la probable relación sentimental de la reina Isabella con Mortimer, a algunas de estas causas o a todas ellas.

Clasificada la violación por Bracton (c. 1210-1268) -autor del mayor compendio de leyes de Inglaterra, basadas en el ius commune, hasta el siglo XVIII- en el apartado De criminibus capitalis, solo detrás, en gravedad, respecto a los delitos contra la corona (De criminibus quae pertinent ad coronam), llevó casi siempre aparejada la muerte, durante gran parte de la Edad Media en Europa. En la época de Bracton, con más frecuencia, solo la castración y desorbitación ${ }^{25}$, que cabe especular

${ }^{24}$ P. Doherty, Isabella and the Strange Death of Edward II. Londres, Headline Pubs.I Hachette Group, 2013.

25 "Among other appeals there is an appeal called the rape of virgins. The rape of virgins is a crime imputed by a woman to the man by whom she says she has been forcibly ravished against the king's peace. [If he is convicted of this crime [this] punishment follows: the loss of members, that there be member for member, for when a virgin is defiled she loses her member and therefore let her defiler be punished in the parts in which he offended. Let him thus lose his eyes which gave him 
llevaría, en todo caso, a la muerte más o menos inmediata, a un cierto número de reos sometidos a este castigo, generalmente en el mismo acto, sin que quepa descartar un número indeterminado de supervivientes. Ya en la Baja Edad Media «[p]ara castigar estos delitos no enmendables el rey disponía de la vida y los miembros del reo y de todas sus propiedades ${ }^{26}$ siendo a menudo la emasculación y/o vaciado de los ojos meramente prolegómenos de la ejecución. Delitos no enmendables eran las denominadas felonies (muerte violenta, violación, asalto con armas) y treason (alta, contra el rey, o menor, contra el superior, habitualmente el señor feudal o un miembro de la nobleza). Una de las modificaciones fundamentales en la pena tiene lugar con la aprobación del Statute of Westminster II, segundo Estatuto de Westminster (1285), que eleva expresamente el tipo penal de la violación a felonía y lo penaliza con «miembro y vida ${ }^{27}$, impidiendo la reparación económica del daño como técnica compensatoria o procedimiento subsidiario. De todas formas, no parecía ser muy frecuente la denuncia de estos delitos y, del total de las denuncias, solo aproximadamente un tercio prosperaban. Otro tercio no eran admitidas a trámite y el otro tercio incluía desestimaciones, a veces seguidas por procedimientos por difamación, injurias o calumnias contra la denunciante ${ }^{28}$. Conseguir que prosperara una denuncia no era fácil. Sin embargo, es menester destacar, en este punto, que, sensu contrario, resulta de un notable simplismo con escasa vinculación a la realidad

sight of the maiden's beauty for which he coveted her. And let him lose as well the testicles which excited his hot lust. Punishment of this kind does not follow in the case of every woman, though she is forcibly ravished, but some other severe punishment does follow, according as she is married or a widow living a respectable life, a nun or a matron, a recognized concubine or a prostitute plying her trade without discrimination of person, all of whom the king must protect for the preservation of his peace, though a like punishment will not be imposed for each. In times past the defilers of virginity and chastity [suffered capital punishment], as did their abettors, since such men were not free of the crime of killing, especially since virginity and chastity cannot be restored, and since virgins and widows as well as nuns are dedicated to God [and] their defilement is committed not only to the hurt of mankind, but indeed, in scorn of Almighty God Himself, and [since] without punishment of this kind such infamy may not be put down. But in modern times the practice is otherwise and for the defilement of a virgin they lose their members, as aforesaid, and their abettors suffer severe corporal punishment but without loss of life or members.]». (H. BRATton, De legibus et consuetudinibus Anglix, c. 1220-1250. Trad. Samuel E. Thorne. Harvard Bracton Online English and Latin Edition, vol. 2, pp. 414-415. http://amesfoundation.law.harvard.edu//Bracton/Unframed/English/v2/415.

${ }^{26}$ L. IgLeSIAS-RÁbADE, «Las penas corporales en el derecho hispánico e inglés en la Edad Media. Estudio comparado». Revista de Estudios Histórico-Jurídicos (Valparaiso), vol. XxxviII, 2016, p. 136.

27 Statute of Westminster II (1285), c. 34. En cambio, el Statute of Westminster I, c. 13 (1275) solo prescribe la pena de encarcelamiento durante dos ańos para el convicto de violar a una mujer, tras cuyo periodo podía pagar una indemnización en cuantía determinada por el rey. http:// www.legislation.gov.uk/aep/Edw1/13/1.

28 Vid. D. Pallotti, «A Most Detestable Crime'. Representations of Rape in the Popular Press of Early Modern England». LEA-Lingue e Letterature d'Oriente e d'Occidente, vol. 1, n. ${ }^{\circ} 1$, 2012, pp. 287-290. 
-como sostiene Lindsay McNellis ${ }^{29}$ - la extendida percepción de la mujer medieval popularizada por la antropología de Lévy-Strauss, en virtud de la cual desde que las mujeres empezaron a ser transferidas entre tribus han funcionado como meros objetos en las vidas de los hombres:

In the Middle Ages, they strengthened family alliances, cemented treaties, and caused or ended wars. However, unlike studies that lament the fate of women and their horrible treatment by men, this study suggests that women also used the system and the men in their lives, to their own advantage. If women's and social history has proven anything, it is that women of the past were far from powerless and that most men held less power than one might believe. Scholars who place women into a category of helpless victim do a great disservice to historical writing ${ }^{30}$.

Personajes de textos literarios como lady Bertilak en Sir Gawain and the Green Knight o Allisoun, o la propia comadre de Bath, en The Canterbury Tales, prueban que no todas eran víctimas indefensas. En este apartado analizamos la representación del crimen en la literatura inglesa tardomedieval para verificar cómo refleja (y a veces anticipa) los cambios en la consideración (juicio y castigo) de estos delitos, que se produce en Inglaterra en la transición del Medioevo al Renacimiento. Por obvias razones de economía, hemos escogido un único autor y una tipología (violencia sexual) en Los cuentos de Canterbury de Geoffrey Chaucer.

Pocos temas han generado tanta controversia entre los críticos de Chaucer como la violación de la doncella por el caballero sin nombre y su posterior jui-

${ }^{29}$ L. McNellis, Let Her Be Taken: Sexual Violence In Medieval England. Orlando, University of Central Florida, 2008, pp. 4-5. McNellis (pp. 66-68) cita en su tesis varias fuentes estadísticas, algunas de las cuales sugieren que solo un $10 \%$ de los casos acababa en condena, y de estos muchos se saldaban en el siglo XIII con una compensación económica. Su propia investigación de 108 casos arroja los siguientes resultados: $15 \%$ de condenas (pero sin que consten ejecuciones ni castraciones); $12 \%$ de acuerdos extrajudiciales (frecuentemente matrimonios y/o compensaciones económicas); $33 \%$ de causas desestimadas (por incomparecencia de la demandante, por cuestiones procesales o por veredictos de no culpabilidad); del $35 \%$ no se ha encontrado la sentencia por deterioro del soporte documental; el 5\% de causas se reenvían a otro tribunal de superior instancia, el 'Shire Court' (tribunal del condado). El porcentaje de resoluciones satisfactorias para la demandante, aunque pueda parecer bajo, es el mismo que para otros delitos como el homicidio. No deben ser tampoco cifras muy distintas a las actuales, en torno al 10\%, según el INE: en 2017 solo hubo en España cinco condenas por violación y 103 por agresiones sexuales, de un total de unas 1200 denuncias. Vid. http://www.ine.es/jaxiT3/Datos.htm?t=28750.

30 «En la Edad Media, fortalecían alianzas familiares, cementaban tratados e iniciaban o ponían fin a guerras. Sin embargo, a diferencia de los estudios que se lamentan de la suerte de las mujeres y el horrible trato que les dispensaban los hombres, este estudio sugiere que las mujeres también utilizaban para su propio beneficio el sistema y a los hombres que se encontraban a lo largo de sus vidas. Si las historias de las mujeres y la historia social han probado algo, lo que han probado es que las mujeres del pasado distaban mucho de estar indefensas y que la mayor parte de los hombres tenían menos poder de lo que se cree. Los académicos que sitúan a las mujeres en la categoría de víctimas indefensas prestan un flaco favor a la investigación histórica». [Mi traducción] 
cio, que desencadena la trama de El cuento de la comadre de Bath ${ }^{31}$. La violación, al menos en el ámbito de la formalidad legal, era considerada, en la literatura jurídica y popular de la época que nos ocupa, 'a most detestable crime', 'a heinous crime', por tanto una suerte de crimen atroz, penado, como mínimo, en la legislación aplicable en el siglo XIV con el vaciado de las cavidades oculares y la posterior emasculación (y frecuentemente con la muerte) especialmente, como hemos visto más arriba, si la víctima era virgen, caso de la doncella de este cuento chauceriano sobre una comadre de Bath.

Hay que comenzar por admitir que ni esta es la única cuestión jurídica en la obra de Chaucer ni la cuestión de la violación carecía de un especial interés para nuestro autor, en la medida en que, poco después de completar su formación jurídica e iniciada su práctica de la misma en los diversos puestos de la administración que desempeñó a lo largo de su vida, se estaba produciendo en Inglaterra una transformación decisiva en la regulación del derecho penal en general y de los delitos de violación en particular. Tampoco hay que olvidar que, hasta que fue exonerado de todos los cargos por la propia presunta violada ${ }^{32}$, el propio Chaucer tuvo que afrontar una acusación penal por este delito, y debió hacerlo durante un periodo de transición, objeto hoy de interminables polémicas, al aplicar conceptos e ideologías contemporáneas a los textos legales y a los literarios de esta época. No es este de la crítica contemporánea, interminable y complejísima, parte de la cual, por cierto, no ahorra acusaciones de misoginia y violencia al autor de los cuentos, el objeto central de mi atención en este apartado, por lo que procuraré no alejarme de esa única objetividad que resta, la de los textos, para explorar desde su literalidad una interpretación plausible del enjuiciamiento y castigo que propone Alyson, la comadre de

31 Algunas contribuciones a este debate, representativas de la crítica a este respecto, son Ch. Cannon, "Chaucer and Rape: Uncertainty's Certainties». Studies in the Age of Chaucer, vol. 22, 2000, pp. 67-92; Ch. Cannon, «Raptus in the Chaumpaigne Release and a Newly Discovered Document Concerning the Life of Geoffrey Chaucer». Speculum, n. ${ }^{\circ}$ 68.1, 1993, pp. 74-94; D.R. CarLson, «The Robberies of Chaucer». English Studies in Canada, vol. 35, n. ${ }^{\circ} 2 / 3$, 2009, pp. 29-54; H. Braddy, «Chaucer, Alice Perrers, and Cecily Chaumpaigne». Speculum, 52.4, 1977, 906-911; J. Mann, Feminizing Chaucer. Cambridge, D.S. Brewer, 2002; M.M. Crow y V.E. LeLAND, "Chaucer's Life». The Riverside Chaucer, Oxford, Oxford University Press, 1987, pp. XI-Xxi; D. Pearsall, The Life of Geoffrey Chaucer. Oxford, Blackwell, 1988, pp. 135-138; S. Soвecki, «Wards and Widows: Troilus and Criseyde and New Documents on Chaucer's Life». ELH, Johns Hopkins University Press, vol. 86, n. ${ }^{\circ}$ 2, 2019, pp. 413-440; S.S. MorRison, «The Use of Biography in Medieval Literary Criticism: The Case of Geoffrey Chaucer and Cecily Chaumpaigne». The Chaucer Review, vol. 34, n. ${ }^{\circ}$ 1, 1999, pp. 69-86; Ch.M. Rose, «Reading Chaucer Reading Rape», Chapter 1. Representing Rape in Medieval and Early Modern Literature, ed. E. Robertson and Ch.M. Rose, Nueva York, Palgrave, 2001, pp. 21-60. T. Pugh, "Chaucer's Rape, Southern Racism, and the Pedagogical Ethics of Authorial Malfeasance». College English, vol. 67, n. ${ }^{\circ}$ 6, 2005, pp. 569-586.

32 «That on May 4, 1380, Cecily Chaumpaigne had enrolled in Chancery a document that released Chaucer of "all manner of actions such as they relate to my rape or any other thing or cause" ["omnimodas acciones tam de raptu meo tam de aliqua alia re vel causa"] is a fact that few now would try to put by». Christopher CANnON, "Chaucer and Rape: Uncertainty's Certainties». Studies in the Age of Chaucer, vol. 22, 2000, p. 68. 
Bath, en su cuento, desde su propia perspectiva histórica y en sus propios términos. Es bien sabido que la ambigüedad suele traer consecuencias manifiestamente mejorables para la justicia; el mismo Chaucer fue probablemente víctima de la ambigüedad terminológica de la palabra 'raptus', que, en el siglo xiv, servía tanto para rapto o secuestro como para violación, para una escapadita de novios como para un grave delito. Originalmente 'raptus' podía significar, desde la perspectiva de la terminología penal, coito forzado, abuso sexual, agresión sexual, abducción, robo con inmediata huida con los objetos sustraídos, etc. Sin embargo, a partir de 1155, 'raptus' solía usarse solamente para abducciones violentas con el propósito de practicar un coito a la fuerza ${ }^{33}$.

En «Chaucer and Rape: Uncertainty's Certainties»" ${ }^{34}$, el ya citado Christopher Cannon estudia con detalle el rol de Geoffrey Chaucer en el 'rapto' de Cecily Chaumpaigne, no desde la perspectiva de la terminología o de la lexicografía histórica, sino a través de la consideración de los fundamentos sobre los cuales un acto sexual concreto puede describirse como consentido o no consentido, asunto extraordinariamente complejo, como muestra tanto la jurisprudencia medieval como la contemporánea. La violación, entonces y ahora, es un crimen atroz e implica un grado de depravación tal que invita a la cautela y a planteamientos de lógica prudencia, cuando se trata de fijar la naturaleza del delito y establecer la carga de la prueba. En este sentido, no existe, hasta donde se sabe, evidencia alguna de que Chaucer violara a Cecily; la crítica ha especulado desde finales del siglo xix que puede que la sedujera, que ella se enfadara con él, y más aún con ella misma, tras una posible negativa del primero a continuar la relación... No lo sabemos. Puede que ella hubiese llegado a la conclusión sincera de que lo que sucedió sucedió de mala manera (en contra de su buen juicio) y que por tanto ocurrió, de algún modo, sin su consentimiento, cuya prueba era y es asunto que genera grandes controversias. O puede, simplemente, que buscase, como sostiene Derek Pearsall ${ }^{35}$, alguna compensación económica por la percepción de una ofensa, que podía tener que ver, o no, con el delito de violación.

${ }^{33}$ Sobre la evolución de la definición de 'raptus' y la presencia del tema de la violación en Los cuentos de Canterbury desde una perspectiva feminista, véase Christine M. Rose, «Reading Chaucer reading rape». Rose, C. y Robertson, E. (eds.), Representing Rape in Medieval and Early Modern Literature. NY, Palgrave, 2001, pp. 21-60; pp. 28-29.

34 Vid., a título de ejemplos representativos de diversas posiciones críticas, los citados en la nota 31 y en las notas 34 a 37 .

35 D. Pearsall, Life of Geoffrey Chaucer. Oxford, Blackwell, 1990, pp. 135-138. «The strongest likelihood, in my opinion, is that Cecily threatened to bring a charge of rape in order to force Chaucer into some compensatory settlement and that she then cooperated in the legal release. The actual offence for which she sought compensation is not necessarily the offence named in the charge that she used for leverage and did not press: there are many things that it might more probably have been than violent physical, rape, including neglect and the betrayal of promises by the man or some unilateral decision on his part to terminate an affair that he regarded as over but which the woman, in retrospect, regard as a physical violation [...]». 
F.T. Plucknett ${ }^{36}$ concluye un estudio sobre el caso estableciendo que nada sugiere que, de tener ocasión, Cecilia hubiese condenado a Chaucer por un delito grave. Sin embargo, la imagen distorsionada de la Edad Media en la cultura popular, como periodo oscuro en el que se supone (sin pruebas) que se da con mayor frecuencia la violencia sexual contra la mujer ${ }^{37}$ y la ampliación conceptual que tiende a imponerse en nuestros días de la necesidad de consentimiento explícito, hace que la relectura desde el presente de textos como el que nos ocupa tienda a consistir en un ejercicio más ideológico que hermenéutico, más político que crítico. Seguramente por estas razones hace ya décadas que parece haber dejado de considerarse repugnante la mera insinuación de que el nombre del primer gran poeta de la lengua inglesa pueda asociarse, aun especulativamente, a un delito como la violación; y todo ello a pesar de que una parte de la crítica académica de máxima solvencia (por ejemplo Caroline Dunn o el ya citado T.F.T. Puckett) no han dejado de explicar que, en el caso de Chaucer, por ejemplo, gran parte de la acusación se sustenta en una incomprensión de la polisemia del término 'raptus', que sirve tanto para una presunta abducción -ilocalización de una pareja durante un determinado periodo- como para la violación, así como en la presunción de veracidad de las denuncias, frente al principio universal del presunción de inocencia ${ }^{38}$. Frente al planteamiento, jurídicamente

36 F.T. Pluknett, «Chaucer's Escapade», The Law Quarterly Review, 64, 1948, p. 35.

37 No constan evidencias de que esto fuera realmente así, comparada la Edad Media, por ejemplo, con el Renacimiento o con la actualidad. La cultura popular presenta, como en el caso de series populares como Juego de Tronos (basada en la novela $A$ Song of Ice and Fire de George R.R. Martin, 1996-...) hasta 200 violaciones más o menos explícitas. Desde la primera temporada (2011) a la quinta (2015) la mayor parte de los personajes femeninos había sido víctima de violación, al menos en grado de intento: Sansa, Cersei Lannister, Daenerys Targaryen, Meera Reed, Gilly y otras veinticuatro mujeres. Interpelado el autor por una parte de la audiencia, algo molesta, responde que así sucedía 'en la brutal Edad Media', lo que dista mucho de ser aceptado pacíficamente por la historiografía actual. En declaraciones a The New York Times, en respuesta a la pregunta de por qué incluía tantas violaciones en sus obras, respondió: «An artist has an obligation to tell the truth. My novels are epic fantasy, but they are inspired by and grounded in history [...]. To omit them from a narrative centered on war and power would have been fundamentally false and dishonest, and would have undermined one of the themes of the books: that the true horrors of human history derive not from orcs and Dark Lords, but from ourselves. We are the monsters». Sin embargo, "If we look at Scandinavia, there is no evidence that rape was more common in the Middle Ages than in the two centuries that followed, or the 1500s and 1600s, says Fredrik Charpentier Ljungqvist. Ljungqvist is a historian at Stockholm University and has conducted two separate studies of the Middle Ages. Hans Jacob Orning is an expert in the Middle Ages from the University of Oslo. He points out that researchers would have found far more evidence of rape in the extensive literature we have from the Middle Ages, if it had been common at that time. "The culture of the Vikings and the Middle Ages was a culture of honour," he said. "Women were an integral part of this culture. Raping a woman would not only have been an assault against her, but also against the community around her." Indeed, rapists were subject to the strictest possible punishment under the law of the time. Rapists were wanted criminals. "If you had raped a woman, anyone could kill you without risking punishment themselves," Orning says». Cfr. http://sciencenordic.com/was-rape-common-middle-ages.

38 Vid. C. Dunn. "The language of ravishment in Medieval England». Speculum, vol. 86, n. ${ }^{\circ}$ 1, 2011, pp. 79-116. "Two pillars of medieval English literature, Chaucer and Malory, stand accused by posterity as criminals, yet scholars remain perplexed about the nature of their crimes 
impecable, de Plucknett, que insiste en que la gravedad del crimen debe convertir (y convierte jurídicamente) 'la incertidumbre de la culpa en certeza de inocencia', en elegante expresión de Ch. Cannon, del principio de presunción de inocencia, porque la documentación que consta no muestra evidencias, autoras como Carolyn Dinshaw vuelven a ponderar, a los meros efectos polémicos, tal posibilidad: a su parecer, «hemos de considerar que hay violaciones reales y 'ficcionales' ayudándonos a desentrañar lo que es figurativo y lo que no en la poética sexual de Chaucer»-lo que quiera que tal cosa pueda significar ${ }^{39}-$. En estas cuestiones, parece razonable sostener

over five centuries later. Some convict them of the heinous offense of sexually assaulting a woman against her will, while others believe them guilty of no more than seduction or consensual sex. The allegation against Malory has even been reframed to portray him as a knight in shining armor rescuing a damsel (or wife) in distress; thus instead of seizing a woman in order to rape her, this author of Arthurian legends "stole" Joan Smith away from her abusive husband when Joan departed with Malory consensually». Vid. también su resumen de fuentes que refutan o afirman la posición de Plunckett, como el trabajo ya citado de Cannon: Ch. CANnon, "Chaucer and Rape: Uncertainty's Certainties», pp. 255-280; «Raptus in the Chaumpaigne Release and a Newly Discovered Document Concerning the Life of Geoffrey Chaucer", pp. 74-94; H.A. Kelly, "Meanings and Uses of Raptus in Chaucer's Time», first published in 1998 and reprinted in Inquisitions and Other Trial Procedures in the Medieval West, Variorum Collected Studies Series 708, Aldershot, 2001, pp. 101-65, en pp. 101 y 119; D. Pearsall, The Life of Geoffrey Chaucer: A Critical Biography (Oxford, 1992), pp. 135-138; Corinne SAUnders, Rape and Ravishment in the Literature of Medieval England (Woodbridge, Eng., 2001), p. 72; H. BRaddy, "Chaucer, Alice Perrers, and Cecily Chaumpaigne», pp. 906-911; M.P. Harley, «Geoffrey Chaucer, Cecilia Chaumpaigne, and Alice Perrers: A Closer Look». Chaucer Review, 28, 1993-94, pp. 78-82; P.R. Watts, «The Strange Case of Geoffrey Chaucer and Cecilia Chaumpaigne». Law Quarterly Review, 63, 1947, pp. 491-513; and T.F.T. Plucknett, "Chaucer's Escapade». Law Quarterly Review, 64, 1948, 33, p. 79.

${ }^{39}$ El complejo estado de esta cuestión ha sido acertadamente resumido, en una publicación más reciente respecto a las originales ya citadas, por CH. CANNON, «Chaucer's rape: Uncertainties' certainties", en E. Robertson y Ch.M. Rose (eds.), Representing Rape in Medieval and Early Modern Literature, Londres, Palgrave, 2001, pp. 256-257: «Gone are the days when conjoining Chaucer's name to the crime of rape seemed repugnant even to those scholars who would address its possibility. In place of Plucknett's insistence that the gravity of such a crime converts uncertain guilt into certain innocence-where the documents that raise the issue provide "no evidence" -we now have Carolyn Dinshaw's demonstration that the conjunction makes us better readers: as it "invites us to consider causal relationships between gendered representation and actual social relations between men and women", we may acknowledge that there are "real rapes" as well as "fictional rapes" and thereby learn to see what is and is not "figurative" in Chaucer's "sexual poetics". That on May 4, 1380 Cecily Chaumpaigne had enrolled in Chancery a document that released Chaucer of "all manner of actions such as they relate to my rape or any other thing or cause" ["omnimodas acciones tam de raptu meo tam de aliqua alia re vel causa"] is a fact that few now would try to put by: it is, as Dinshaw also says, "perhaps the one biographical fact everyone remembers about Chaucer". And the resilience of that memory, we have also learned to recognize, is not simply due to the gravity of the released crime. As Jill Mann has shown, the subject is one that Chaucer does not himself shrink from: throughout his writing "rape remains a constant touchstone for determining justice between the sexes". But, if we have arrived at a stage where considering Chaucer and rape together no longer seems dangerous, if we are even able to make that consideration critically enabling, we are not yet at a stage where the Chaumpaigne release seems able to teach us anything more than we are willing to presume. Clearer understanding of the role rape may play in Chaucer's poetics has not been born in any clearer understanding of what precisely the Chaumpaigne release refers to, largely because 
que lo mejor es atenerse a lo que puede considerarse cierto y controlar las especulaciones sin base fáctica o documental alguna: tenemos el documento en el archivo de la Court of Chancery, registrado de entrada el 4 de mayo de 1380, en el que Cecily Chaumpaigne exoneraba a Geoffrey Chaucer de toda acusación de rapto o violación: «Omnimodas acciones tam de raptu meo tam de aliqua alia re vel causa ${ }^{40}$.

No obstante, planteada la posibilidad de perder la vida, aunque finalmente Cecily efectivamente testificase a su favor, no solo resulta imposible que tal experiencia no dejase una traza en la memoria de nuestro autor, que bien pudiera haber influido en la producción literaria posterior, sino que también se habría convertido en un tema personal, que bien puede conjurarse, si se torna en un criterio definidor de la justicia entre los sexos, tal y como lo aborda Chaucer en sus textos. El lenguaje jurídico medieval al conformar el ambiguo concepto de raptus lo convierte en un posible crimen atroz, pero también ofrece un modo de resolver las dificultades de tipificación y sanción de dichos delitos.

El historiador inglés John M. Carter, en su estudio de la violación en la Inglaterra medieval de los siglos XIII y XIV, sugiere que en estos años en que aún competía el derecho común con las cortes eclesiásticas, estas últimas tendían a dictar sentencias menos severas que la jurisdicción penal secular, sin que sepamos a ciencia cierta, ni en España ni en Inglaterra, por qué o en qué circunstancias los mismos o muy parecidos hechos acababan en una u otra jurisdicción. Cabe sospechar que el estatus social, estamento de pertenencia y fortuna jugarían un papel determinante en una distribución, que, si bien no sería aleatoria, tampoco parece que fuese siempre y del todo arbitraria. El castigo del delito de violación, concluye Carter, depende de que la comunidad desease matar o mutilar, o ambas cosas, al agresor, en cuyo caso la acusación era de crimen atroz (felony), mientras que, si la comunidad consideraba más apropiado salvar la vida del violador, esta lo haría por razones que

the release is so parsimonious of description while the language and procedure of medieval English law are so frequently ambiguous as they pertain to "raptus". Although I have argued elsewhere that this word must refer to forced coitus in the Chaumpaigne release, central to that earlier argument was the claim that mention of a 'raptus' in fourteenth-century law was itself an attempt to achieve clarity in the face of a legal tradition that had become hopelessly confused about the naming of sexual violence and its punishment. That confusion will always make it possible to say that "raptus" might have been used to describe an "abduction" in the Chaumpaigne release, as has been said in the past, although, I think, not because the term has always had wide reference in Latin (as past claims for "ambiguity" have maintained), but because, first, a legal document in the fourteenth century as well as now is necessarily an instrument at some remove from "what happened" and, second, because sexual violence is itself a crime where "what happened", the very act that might constitute the crime, can be variously defined even by those who have identical "facts" in hand. The first point is clear enough even to the casuist Plucknett: although he is certainly wrong to suppose that uncertainties about the Chaumpaigne release's historical witness are themselves necessarily absolving, he is certainly right that even if raptus refers to "rape" in that release (which he believes) this does not demonstrate that Chaucer raped Cecily Chaumpaigne».

40 Vid. Ch. Cannon, «Raptus in the Chaumpaigne Release and a Newly Discovered Document Concerning the Life of Geoffrey Chaucer». Speculum, 68, 1993, p. 89. https://chaucer.fas.harvard.edu/pages/cecily-chaumpaignes-deed-release. 
podían ir desde la existencia de un pacto sobre la compensación económica de una futura dote, resultado de un eventual matrimonio de la víctima y su agresor, hasta la diferencia de estamento, clase social se diría más adelante, entre uno y otra. En este caso, podía instruirse la causa como allanamiento (trespass).

Desde el punto de vista procesal, el juzgado competente para conocer de este delito era la Audiencia o Juzgado de lo Criminal (Court of Assizes), que se reunía dos veces al ańo, en primavera y verano, y se encargaba en primera instancia de la instrucción del caso. Se tomaba juramento a un gran jurado, que recibía el acta de acusación (bill of accusation), tomaba noticia de los términos y pruebas de los que disponía la acusación y decidía si las evidencias aportadas eran suficientes para proceder al acto de juicio. Las actas declaradas ciertas por el gran jurado se trasladaban a la Audiencia, que procedía a la acusación formal, imputación del cargo y al correspondiente encausamiento. La fase de juicio solía ser muy breve, una media hora, desde la declaración de procesamiento al alegato final, al que seguía la deliberación del jurado. Con las muy reiteradas cláusulas de salvaguarda respecto a la contingencia de las estadísticas, el número de vistas por violación era escaso, sin que resulte viable dirimir ahora los porcentajes que eran resultado de ausencia de denuncia por parte de la víctima, retirada de cargos, inadmisión de demandas, acuerdos matrimoniales o compensatorios de carácter extrajudicial, etc. No ha de olvidarse tampoco la existencia de casos documentados, en los que la acusación era pactada entre novios cuyos familiares se oponían a la relación, para posibilitar un matrimonio que por lo demás resultaría inviable.

Cabe asumir, no menos, ni más, especulativamente que Pluckett o Dinshaw, que el interés objetivo en la violencia sexual que muestra Geoffrey Chaucer en su producción literaria pudiera estar conectado de algún modo con los hechos de su biografía antes descritos; estos sucedieron, por cierto, cuando tenía unos 37 años y una posición social ya establecida, en el servicio diplomático del rey Ricardo II, lo que introduce un elemento adicional a considerar si se especula sobre la posibilidad de una denuncia falsa; el poder y la influencia de Chaucer se incrementan al controlar prácticamente todo el gobierno su protector Juan de Gante, tío del nuevo rey Ricardo II. En este contexto, pueden existir dudas razonables tanto sobre cómo hemos de interpretar tales representaciones literarias como sobre las consecuencias naturales de las dudas y cuestiones que la reiteración del tema en sus cuentos más populares plantean al lector y al crítico; en esto consiste, en última instancia, la literatura, que no es arte de resolver problemas, sino de plantearlos con inteligencia para que cada lector los resuelva a su modo.

Por poner solo algunos ejemplos notables de las frecuentes visitas de nuestro autor al tema de la violencia sexual o la violación, El cuento del administrador (The Reeve's Tale), uno de los más favorecidos con el éxito por el público y la crítica, describe cómo uno de sus protagonistas, Alano, consigue introducirse en el lecho de Molly, la hija de un molinero, informando el narrador de que era demasiado tarde para que ella pudiera gritar pidiendo auxilio (sorprendente afirmación, si se tiene en cuenta que sus padres duermen a escasos centímetros de ella), mientras que Juan hace lo propio con la esposa del anfitrión, que se acuesta en la cama del invitado creyendo que era la propia. No queda claro en el texto si estas dos mujeres, como tantas otras en diferentes obras de Chaucer, rechazan el sexo prematrimonial, intra- y/o extra- 
marital en las ambiguas situaciones que describe el autor, que juega con la ironía y con los malentendidos, siempre al filo de la navaja; por una parte, parece extraño, desde la perspectiva de la lógica, que Molly y su madre, de la que no conocemos el nombre, actúen de forma que parezca evidente su consentimiento; o, sensu contrario, que no encontremos en el texto que hagan constar en modo alguno la más mínima expresión de falta de consentimiento, sino más bien lo contrario:

But faire and wel she creep in to the clerk,

And lith ful stille, and wolde han caught a sleep.

Withinne a while this John the clerk up leep,

And on this goode wyf he leith on soore.

So myrie a fit ne hadde she nat ful yoore;

He priketh harde and depe as he were mad.

This joly lyf han thise two clerkes lad

Til that the thridde cok bigan to synge.

[...]

"Now, deere lemman", quod she, "go, far weel!

But er thow go, o thyng I wol thee telle:

Whan that thou wendest homward by the melle,

Right at the entree of the dore bihynde

Thou shalt a cake of half a busshel fynde

That was ymaked of thyn owene mele,

Which that I heelp my sire for to stele.

And, goode lemman, God thee save and kepe!"

And with that word almoost she gan to wepe ${ }^{41}$.

Puede argüirse que leemos el texto desde la perspectiva de los estudiantes, desde el punto de vista del propio cuento, que se vehicula principalmente a través de los actores principales, de la voz narrativa de Chaucer; podría plantearse que, en el fondo, la intención de los estudiantes era vengarse en los cuerpos de la esposa y la hija, y dar una lección al molinero, que los había estafado. Al final de la historia, cada uno de los estudiantes ha conseguido yacer, sin pedir consentimiento expreso ni sufrir consecuencias legales, con la madre y la hija respectivamente; ambas, como hemos visto más arriba, parecen satisfechas con lo ocurrido al final del cuento y, además, los estudiantes se llevan un pastel gratis y tampoco pagan su pernoctación.

${ }^{41}$ G. Chaucer, The Reeve's Tale. Harvard Interlinear Edition, v. 4226-4233 y 4240-4248. https://chaucer.fas.harvard.edu/pages/reeves-prologue-and-tale; Las citas de Los cuentos de Canterbury en español están tomadas de la versión de Pedro Guardia Massó: G. Chaucer, Cuentos de Canterbury. 15. ${ }^{a}$ ed., trad. y ed. P. Guardia Massó. Madrid, Cátedra, 20018, p. 160: «[...] se introdujo [la madre de Molly] en el lecho del estudiante. Se quedó quieta y se hubiese dormido si Juan, cobrando vida, no se hubiera echado encima de la buena mujer. Ésta pasó el mejor rato que había gozado en años, pues él la trajinó como un loco, entrando a por uvas con fuerza. [...] Entonces ve, cariño, y adiós -replicó ella [Molly]; pero te confesaré algo antes de irte: cuando os marchéis a casa, al pasar frente al molino, detrás de la puerta, encontraréis un pastel confeccionado con dos arrobas de vuestra harina, que ayudé a mi padre a robar. ¡Que Dios te bendiga y te proteja, cariño!». 
Cabe especular que el punto de vista de ellas fuera quizá otro: es posible que Molly no gritara para evitar la vergüenza de ser descubierta, por el presunto daño irreparable que esto podría traer a su reputación y a sus posibilidades de matrimonio; o quizá la madre creía sinceramente haber estado yaciendo con su marido y no con el estudiante, a pesar de las evidentes diferencias físicas de ambos. Todos estaban borrachos y tal circunstancia podía haber nublado en alguna medida sus entendimientos. Como en la mayor parte de los fabliaux (como en El cuento del molinero), el orden queda restaurado, paradójicamente, a través de una conducta ambigua entre, como mínimo, desordenada (en tanto que adúltera) y, como máximo, directa y gravemente delictiva, si es que se interpretara como violación. La cuestión principal, sin embargo, sigue siendo que el cuento es una comedia; que la mayoría de los ciudadanos del Medioevo (hasta nuestros días) admiten que esta representación de una 'violación' es divertida porque, en el fondo, nada hay en el texto que indique ni consentimiento expreso ni ausencia de consentimiento; más bien los indicios textuales apuntan a un consentimiento ex post de ambas y desde el principio en el caso de Molly. Cuando llega el alba y Alano anuncia su marcha a Molly, esta le despide con afecto, le regala un pastel y casi se echa a llorar por la despedida de su amante. Parece que quisiera premiar a Alano con un pastel para reparar la culpa del robo organizado por su padre, en el que ella fue cooperadora necesaria, y que lamenta de corazón la marcha de aquel con quien ha pasado la noche, el cual, en todo momento, se dirige a ella con afecto, delicadeza y respeto. Por su parte, de la madre de Molly dice el narrador que pasó el mejor rato que había gozado en años, sin que tampoco esta planteara oposición alguna, aunque flota en el aire la duda sobre la percepción de la identidad del amante.

Chaucer aborda aquí la compleja cuestión del consentimiento, abriendo un amplio margen de discrecionalidad conceptual e interpretativa y manifestando sin ambages que existía en su tiempo un mayor ámbito de libertad de expresión para la inclusión en la comedia, aun con este componente de ambigüedad, de elementos cómicos en la descripción de una supuesta violación; hoy se habría censurado al autor, seguramente hasta el ostracismo, bajo el pretexto de que estos chistes sobre violaciones no deben pronunciarse, mucho menos ser susceptibles de vehicular comedia o humor literarios, porque hacen mofa de la víctima y normalizan la cultura de la violación.

Por su parte, en Leyenda de buenas mujeres, Legend of Good Women (13851396), encontramos al menos dos violaciones; se trata de un texto satírico que versa más bien sobre hombres perversos que sobre mujeres buenas, una leyenda de mujeres que creen en sus amantes y acaban abandonadas, desesperadas, cuando no muertas, como con la primera leyenda, la de Cleopatra, en donde las mujeres reciben por su virtud abandono y violaciones hasta que cinco de ellas se suicidan ${ }^{42}$.

42 Vid. Peter L. Allen, «Reading Chaucer's Good Women». The Chaucer Review, vol. 21, n. ${ }^{\circ}$, 1987, pp. 19-20. 
Junto con El cuento del administrador, cabe identificar el tema de la violación (incluido el grado de intento) en al menos siete cuentos más: El cuento de la comadre de Bath, El cuento del mercader, El cuento de Melibeo, El cuento del magistrado, El cuento del médico, El cuento del ecónomo y El cuento del Terrateniente. También en el propio prólogo general a Los cuentos de Canterbury, encontramos el retrato del bulero (The Pardoner), con no pocas ambigüedades, caracterizado por Chaucer, en el propio texto, como un homosexual o un afeminado: "I trowe he were a geldyng or a mare» (v. 691) / "Lo tomé por castrado o invertido» ${ }^{43}$, no pudiendo determinarse si era un eunuco ex nativitate o como resultado de un castigo por violación, ni siquiera -según el autor-si era un afeminado o un homosexual.

Sin embargo, el texto de Chaucer que probablemente mejor permite la exploración de la violación como delito grave (felony) es El cuento de la comadre de Bath. Este texto es particularmente directo y claro respecto de los hechos enjuiciados, que sitúa en la propia apertura del cuento:

And so bifel that this kyng Arthour

Hadde in his hous a lusty bacheler,

That on a day cam ridynge fro ryver,

And happed that, allone as he was born,

He saugh a mayde walkynge hym biforn,

Of which mayde anon, maugree hir heed,

By verray force, he rafte hire maydenhed;

For which oppressioun was swich clamour

And swich pursute unto the kyng Arthour

That dampned was this knyght for to be deed,

By cours of lawe, and sholde han lost his heed -

Paraventure swich was the statut tho -

But that the queene and other ladyes mo

So longe preyeden the kyng of grace

Til he his lyf hym graunted in the place,

And yaf hym to the queene, al at hir wille,

To chese wheither she wolde hym save or spille ${ }^{44}$.

43 G. Chaucer, The General Prologue to the Canterbury Tales, v. 691: «I trowe he were a geldyng or a mare». Prólogo General a los Cuentos de Canterbury, p. 83.

${ }_{44}$ G. Chaucer, The General Prologue to the Canterbury Tales, v. 882-898: https://chaucer.fas.harvard.edu/pages/wife-baths-prologue-and-tale-0. El cuento de la comadre de Bath, pp. 221222: «Pues bien, sucedió que en la corte del rey Arturo había un caballero joven y alegre. Un día que, montado en su caballo, se dirigía a su casa después de haber estado dedicándose a la cetrería junto al río, se topó causalmente con una doncella que iba sin compañía y, a pesar de que ella se defendió como pudo, le arrebató la doncellez a viva fuerza. Esta violación causó un gran revuelo. Hubo muchas peticiones de justicia al rey Arturo, hasta que, por el curso de la ley, el caballero en cuestión fue condenado a muerte. Y hubiese sido decapitado (tal era, al parecer, la ley en aquellos tiempos) si la reina y muchas otras damas no hubieran estado importunando al rey solicitando clemencia, hasta que al fin él le perdonó la vida y lo puso a merced de la reina, para que fuera ella, a su libre albedrío, la que decidiese si debía ser ejecutado o perdonado». 
La descripción de la escena no deja lugar a dudas ni existen ambigüedades en el relato, al integrar perfectamente los elementos esenciales del delito: sexo no consentido, prevalimiento mediante el uso de la fuerza por parte del caballero ${ }^{45} \mathrm{y}$ resistencia por parte de la doncella, una joven campesina. La ausencia de los nombres del caballero violador y de la joven violada sugieren un planteamiento generalizador por parte de Chaucer, autor realista, que estaría centrándose en tipos más que en individuos; efectivamente, parece querer concentrar la atención del lector sobre un fenómeno y unos tipos sociales (cabe colegir que, en alguna medida, representativos) más que sobre unos personajes individualizados a través de las técnicas convencionales de caracterización de personajes, que tan brillantemente exhibe Chaucer en otras ocasiones (por ejemplo, en el prólogo general). Tal planteamiento enfatiza la transmisión de un mensaje moral abstracto, que entronca fácilmente con la literatura crítica sobre el comportamiento de los señores feudales, ejemplificados en su más famoso mito constitutivo de la nación inglesa (los caballeros de la Tabla Redonda).

Sobre la reacción de la corte del rey Arturo, afirma el narrador, con cierta duda, que la condena a muerte era «al parecer la ley en aquellos tiempos» y no vuelve a referirse a la joven violada en el resto del relato, no dando cuenta de ninguna reparación, al tiempo que transforma el delito en un instrumento de aprendizaje y maduración del caballero; este aprende las lecciones olvidadas del código de caballería: la 'gentilesse' del amor cortés, la virtud de una vida presidida por la pobreza evangélica como modelo cristiano, la construcción de la identidad del caballero más allá del linaje, a través de sus propias buenas obras, etc.; aprende también que la salvación, individual y colectiva, consiste, al menos parcialmente, en otorgar el poder a la dama: «En general, las mujeres desean ejercer autoridad tanto sobre sus esposos como sobre sus amantes y tener poder sobre ellos ${ }^{46}$; experimenta lo que es sentirse forzado, aun sin violencia (hoy habría quienes apreciarían en la escena violencia psicológica), a tener sexo con quien no se desea y la perversión moral de obtener por la fuerza en un sendero junto a un río lo que puede obtenerse consensualmente en el tálamo conyugal: "Greet was the wo the knyght hadde in his thoght, / Whan he was with his wyf abedde ybroght; / He walweth and he turneth to and fro / His olde wyf lay smylynge everemo» ${ }^{47}$.

No aporta Chaucer detalles sobre cómo llegó la denuncia de violación al rey, si por acusación de la víctima, de su familia, por un clamor popular del pueblo a través de la corte o por otro medio. Sorprende también que la justicia del rey decrete la pena de muerte de un noble, sin que medie sospecha de traición, sin cri-

45 Andreas Capellanus, en De Amore Rusticorum, a principios del siglo XIII recomienda a los nobles no mantener relaciones amorosas con campesinas, pero sugiere que si un noble sucumbía a los encantos de una de ellas, ante atracción que pudiera considerarse fuerza irresistible, era mejor que se comportase de un modo salvajemente abrupto y, si fallaba la persuasión, la violase. Vid. Andrae Capelani regii Francorum de Amore libri tres, ed. Amadeo Pages, Castellón, 1930, p. 120.

46 G. Chaucer, p. 225.

47 G. Chaucer, v. 1083-1085; p. 226. «El caballero sufrió mucha angustia mental cuando su mujer lo arrastró a la cama. Él se volvió y revolvió una y otra vez mientras su anciana esposa le miraba sonriendo acostada». 
men político, y sean precisamente la reina y otras damas nobles las que insistan al monarca para que ofrezca la posibilidad de conmutación de la pena, a cambio de su potencial acierto en una especie de juego consistente en la resolución de un acertijo. También resulta sorprendente que la pena de muerte queda definitivamente conmutada en una vista presidida por la reina, en la que la confirmación del acierto por parte del tribunal, con todas las mujeres presentes, se hace por defecto, o lo que es lo mismo, en sentido negativo, lo que permite interpretaciones diversas sobre la variedad de deseos, quizá algunos distintos, de las mujeres presentes, de cuyo dictamen dependía la vida del caballero: "In al the court ne was ther wyf, ne mayde, / Ne wydwe that contraried that he sayde, / But seyden he was worthy han his lyf ${ }^{48}$.

Puede que no sean explicaciones amables las que justifiquen este comportamiento por parte del tribunal, íntegramente femenino, encargado por el rey de juzgar si el caballero había cumplido la condición que le libraría de la pena de muerte. Puede que las damas de la corte fueran conscientes del uso de las acusaciones de violación para obtener matrimonios de conveniencia, venganzas contra enemigos, compensación económica que aumente la dote y compense ese y/u otros deslices anteriores..., o puede incluso que alguna o algunas de ellas lo tuvieran como amante y no desearan su ejecución, sin importarles demasiado la suerte de una aldeana sin nombre.

Tampoco puede desconocerse que, en una de las leyendas más conocidas a finales del siglo xiv, la reina Ginebra mantenía una relación adúltera con uno de los caballeros de la Tabla Redonda, el francés Lanzarote. En La muerte de Arturo de Thomas Malory, la hechicera Morgana (Morgan Le Fay), celosa de la belleza de Elaine de Corbenic, la deja atrapada en un baño de agua hirviendo de la que es rescatada por Lanzarote del Lago. Elaine se enamora de él y no acepta que Lanzarote la rechace porque está enamorado, a su vez, de la reina Ginebra. Conocedora de que no aceptaría tener sexo con ella voluntariamente, Elaine pidió ayuda a la hechicera Dame Brusen, quien le dio una pócima a base de vino y un anillo de la reina Ginebra, gracias a los cuales consigue acostarse con Lanzarote (dos veces), convencerlo de que está embarazada y conseguir que la bese, cuando ya sabía que había sido engañado. Si bien para los estándares de la Edad Media, el concepto de violación parecía restringirse a la agresión sexual de un hombre contra una mujer, no cabe duda de que se trata de un tropo ilustrativo de una doble moral, pues las acciones de Elaine suponen una violación de Lanzarote por parte de una mujer que no está dispuesta a aceptar que aquel que desea no yazca con ella: estamos ante un caso de sexo no consentido, así como un cierto grado de violencia (si bien más sutil, pues se basa en el envenenamiento y el engaño y no en la violencia o el abuso físico o psicológico). No resulta tan extraño, por tanto, debidamente contextualizado el pasaje, en la literatura de su tiempo, que la reina y las damas de la corte solicitaran al rey Arturo el perdón del caballero, siempre que consiguiera el éxito en una aventura del conoci-

48 G. Chaucer, v. 1043-1045; p. 227. «Ni una sola matrona, doncella o viuda en todo el tribunal contradijo tal afirmación [que lo que más deseaban era ejercer autoridad sobre sus esposos y amantes]. Todas declararon que merecía conservar la vida». 
miento que procura, por una parte, poner en el centro de atención a la mujer, reflejar sus verdaderos deseos, al tiempo que educaban al caballero en las virtudes propias de su estamento, como veremos con más detalle más adelante.

Tampoco ha de sorprender que el caballero violador del cuento sea inicialmente condenado a muerte por la agresión sexual a una virgen. Probablemente, la legislación aplicable, a la que se refiere el autor en el pasaje citado, no son los Statutes of Westminster I (1275), que establecían como condena habitual dos años de prisión y multa, sino los Statutes of Westminster II, de una década después (1285), y el Statute of Rapes, de 1382, que incluían la posibilidad de pena de muerte o muerte y desmembramiento; ya han migrado estos Estatutos de la vieja clasificación que trae causa del derecho romano, en la que la violación se considera un delito contra la propiedad de la familia; ahora pasa a ser enjuiciado como crimen contra la persona, castigado con la pena de muerte, aunque su aplicación práctica, en este como en otros delitos, no parecía ser demasiado frecuente, si bien no faltan documentos que avalan su uso; la iniciativa podía ser de la víctima o de los Justicias (otra novedad de la reforma de 1382, Statute of Rapes), pero la solución matrimonial, contra el criterio de la Iglesia, seguía siendo un acuerdo frecuente, judicial o extrajudicial.

No obstante, el nuevo Estatuto de 1382, a diferencia del Westminster II, castiga expresamente con desheredar a quienes, tras denuncia, la retirasen o modificasen la versión de los hechos, tras una oferta de matrimonio. Cuando Chaucer estaba escribiendo Los cuentos de Canterbury, cien años después de la aprobación de los Estatutos de Westminster (y casi tres siglos después de la supuesta época artúrica), crecía el clamor contra la ineficacia de los mismos, al ser escasos los supuestos en que un proceso de 'rapto' acababa con una sentencia de muerte o desmembramiento del agresor. Además, con los Estatutos entonces vigentes, el juzgador se sentía con frecuencia incapaz de establecer la presencia o ausencia de consentimiento de la víctima, que a menudo incomparecía (por múltiples causas, posiblemente la mayoría no imputables a ella) al acto de juicio. El proceso por la denuncia de violación de Eleanor, hija de Thomas West y Alice West, en 1380 fue la gota que colmó el vaso de la paciencia del legislador, que resolvió, a petición del padre, sustituir la regulación procesal de la violación de los Estatutos de Westminster por un nuevo cuerpo legal, el ya citado Statute of Rapes de 1382. Como en El cuento de la comadre de Bath, en el que la aldeana violada desaparece y es sustituida por la anciana, que no se metamorfoseará en bellísima y noble doncella hasta que el violador le haya entregado el dominio de sus actos, la soberanía, Eleanor (la hija presuntamente violada de Thomas y Alice West) desaparece de la escena y una mujer mayor, su madre, se apodera de la historia. Ya la violación no es solo una amenaza contra los intereses patrimoniales de una familia, sino que es, de alguna manera y en un sentido muy moderno, un asalto violento contra el cuerpo y la libertad de una mujer. En el Statute of Rapes de 1382, como resultado de la petición de los West al rey, podemos apreciar la tensión entre la valoración de los deseos de la mujer por una parte y el control familiar sobre el valor del matrimonio, como institución económica, por otra. Una innovación fundamental de este nuevo estatuto de 1382 consiste en declarar culpable al violador, aunque con posterioridad a los hechos la mujer supuestamente lo perdone y 'consienta'; otra innovación, como apuntábamos más arriba, es que convierte a la 
mujer en culpable de su propia violación si después de la misma 'consiente', desheredando tanto al presunto violador como a la violada, por haber realizado un abuso de derecho para conseguir, a través de una denuncia falsa, los objetivos que no conseguían pacíficamente mediante acuerdo previo entre las partes (ellos y sus respectivas familias). En el ámbito procesal, el nuevo estatuto también permitía a las familias demandar sin demoras, garantizando la protección de sus intereses económicos como elemento de equilibro frente a las estrategias de los jóvenes para decidir por sí mismos con quién contraerían matrimonio ${ }^{49}$.

\section{CONCLUSIONES}

Por más que una orientación crítica, desde la ideología de género postcontemporáne $\mathrm{a}^{50}$, venga pretendiendo desmontar la crítica chauceriana que sugiere que G. Chaucer era contrario a la concepción de la mujer como propiedad patriarcal o respecto de su énfasis en la relevancia penal del papel del deseo o del consentimiento femenino frente a su naturaleza económica como propiedad familiar, la realidad es que El cuento de la comadre de Bath, con la condena a muerte del caballero violador (como cuando castiga a todos los personajes masculinos de El cuento del molinero y excepciona a Alisoun), sitúa a Geoffrey Chaucer en la vanguardia de un pensamiento protohumanista, que aborrece este atroz delito contra la mujer y plantea la necesidad de una justicia que se aplique por igual a ambos sexos. También le sitúa en la defensa de una suerte de protofeminismo, entendido como igualdad de estatus, derechos y obligaciones de hombres y mujeres y todo ello sin abandonar la única evidencia objetiva que nos consta en la literalidad del propio texto de Los cuentos de Canterbury, que plantea que, al menos por esta vez, el sistema judicial ha funcionado, con carácter mínimo, hasta la fase de veredicto y condena; cosa distinta es la interpretación que deba darse del uso de la prerrogativa real del perdón del caballero, condicionado por una cues-

49 Hay autoras que plantean el desarrollo del Statute of Rapes de 1382 (Confirmation of Liberties, Charters and Statutes, Legal Proceedings, Rape, etc. Act,1382 c. 1, 3-13) como una mera estrategia de las clases dominantes para retirar a las mujeres el poder de decidir sobre su matrimonio (negativa o positivamente) mediante el uso de la denuncia falsa por 'raptus', manteniéndola o retirándola a cambio de matrimonio u otras ventajas materiales; la bibliografía tiende a 'culpar' de la redacción de este Estatuto de Violaciones a sir Thomas West, quien hizo un efectivo lobby sobre la corona, tras la presunta violación de su hija Eleonor por Nicholas Clifton, de clase social inferior a la suya, con objeto de limitar las pérdidas económicas resultantes de matrimonios desventajosos, organizados por los hijos en contra de la voluntad de sus padres. Vid. S. EDwards, «The rhetoric of rape and the politics of gender in the Wife of Bath's Tale and the 1382 Statute of Rapes». Exemplaria, vol. 23, n. ${ }^{\circ}$ 1, 2011, pp. 4-14; Nicole N. Sidhu, Indecent Exposure. Gender, Politics and Obscene Comedy in Middle English Literature. Filadelfia, University of Pennsylvania Press, 2016, pp. 76-112; y T. Dean, Crime in Medieval Europe 1200-1550. London, Routledge, 2001, p. 84.

50 S. EDwards, pp. 15-23; E. Robertson, «Raptus and poetic married love in Chaucer's Wife of Bath's Tale and James I's Kings Quair». Reading Medieval Culture. Ed. Robert M. Stein and Sandra Pierson Prior. Notre Dame, University of Notre Dame Press, 2005, pp. 302-313. 
tión (la respuesta a la pregunta sobre lo que las mujeres desean más) que ciertamente relativiza e ignora el problema principal que da lugar al cuento y que es la agresión sexual. Del mismo modo, con independencia de las especulaciones sobre los motivos de la redacción del Statute of Rapes de 1382, no cabe duda de que la introducción de la posibilidad de la iniciativa penal por parte del Estado (sin eliminar la denuncia de parte) demuestra una evolución hacia una consideración de mayor gravedad del acto en sí (serious felony en derecho común), al tiempo que la posibilidad de la condena a muerte, con o sin mutilación previa, supone una clasificación del delito como atroz, en tanto que comparte enjuiciamiento y castigo con el grupo de delitos más graves previstos en el ordenamiento jurídico de finales del siglo xiv en Inglaterra.

Por otra parte, resulta imposible afirmar la autonomía de la mujer y requerir que una relación sexual obtenga su consentimiento en un texto legal, sin legislar de modo que se procure evitar el abuso que deviene de la utilización (no precisamente anecdótica en el siglo de Chaucer) del fraude de ley. En esto precisamente había devenido la praxis de aplicación de los Statutes of Westminster, que no abordaban la consideración jurídica que debía darse a la retractación de la doncella presuntamente violada, la cual se venía considerando una conducta lícita, cuando producía un resultado inequívocamente contrario al perseguido por la ley: la disuasión de la violencia sexual contra la mujer o su sanción ex post, evitando que quienes tuvieran medios para hacerlo comprasen la remisión de la pena a través de una mera compensación económica o un matrimonio, que, con toda probabilidad, no se habría producido de no mediar la denuncia; o, sensu contrario, tampoco cabe imaginar que una norma del siglo XIV, ante la probable frecuencia y alarma social de los casos de fraude en algunas denuncias, sancionara dichas denuncias falsas como procedimiento lícito para forzar dotes y herencias, en los casos de desacuerdo entre las familias y los protagonistas de la relación íntima objeto de juicio.

Chaucer escribe sus cuentos en un contexto nuevo, contemporáneo al Statute of Rapes de 1382, contexto cambiante, iniciado tímidamente en el siglo XII, que mostraba una progresiva reclasificación de la violación, iniciada por Glanvill y Bracton, no solo como crimen contra la propiedad familiar y crimen personal (violencia contra las personas), sino también como crimen serio u horrendo, percepción que parece se hallaba muy extendida por toda Inglaterra a finales del siglo xIV; el castigo se había venido endureciendo y era la pena de muerte o desmembramiento, también la extirpación de los ojos o la emasculación, particularmente cuando la víctima era virgen, opciones abiertas al tribunal, que, como sucede en El cuento de la comadre de Bath, tendía a conmutar la pena de muerte e, incluso, con frecuencia, la de emasculación y desorbitación por otras menos severas. La ejecución de Hugh Le Despenser en 1326 incluye dichas penas, en el marco de una acusación de múltiples delitos, incluido el crimen político de alta traición, sin el cual, probablemente, ninguno de los otros habría llegado a juicio. Como atinadamente apunta Beatriz 
Hernández ${ }^{51}$, Chaucer, en cierto sentido, se opone a la tradición misógina, reclama para la mujer un ámbito de poder legítimo, con independencia de que luego pueda, o no, cederlo al marido, como sucede en El cuento de la comadre de Bath, pero nunca sin antes haberse ganado la soberanía, mediante expresiones específicas de su autonomía personal que libran al autor de Los cuentos de Canterbury de la condena fácil frente a las acusaciones de misoginia de que es frecuentemente objeto.

La moraleja final del cuento, como sugirió Trevor Whittock ${ }^{52}$, radica en la libre subordinación de la voluntad del caballero (a diferencia de su imposición por la fuerza al principio de la narración, cuando tomó por la fuerza a la doncella); su reconocimiento de la alteridad de la mujer viene a ser recompensada de varias formas, incluida la comprensión de que para recibir es menester darse; en esto, sugiere Alice, la experimentada comadre de Bath, consiste la felicidad del matrimonio.

Si bien hemos de concluir que el ejercicio de la acción penal por parte de los tribunales raramente imponía a los violadores en la práctica cotidiana lo previsto en la dinámica legislación vigente analizada sobre este exceptional crime (especialmente si el agresor pertenecía a la nobleza y la agredida no), Chaucer ofrece una visión mucho más aguda, sensata, sofisticada y moderna sobre el atroz delito de violación. Obviamente, para apreciar su contribución es menester trascender interpretaciones simplistas que se limitan a reducir el argumento de la obra a un caballero que viola a una doncella, se libra de la pena de muerte y, por si fuera poco, recibe el premio de una esposa que, a la postre, resulta hermosa, joven, obediente y fiel. La voz narrativa elegida por Chaucer para este cuento y para su más que interesante prólogo es Alice, la comadre de Bath, que declara abiertamente su punto de vista («este caballero, sobre el que versa específicamente este cuento») y empieza por condenarle a muerte por su delito de violación, presenta la necesidad de que se contemple dicho crimen como uno de los más graves y lo tipifica como delito contra las personas, no contra la propiedad, delito que conviene sea juzgado por la comunidad. También muestra al lector la terrible pérdida que se estaba produciendo, en el ocaso de la Edad Media, de las verdaderas virtudes de la caballería, al tiempo que azuza al derecho a acometer con decisión los crímenes violentos contra las mujeres. Pocos autores han invitado a sus lectores con tanto éxito como Chaucer a considerar la violación un crimen atroz, merecedor de la pena de muerte, pero también a ponderar las innumerables dificultades que entonces, como ahora, rodean a su enjuiciamiento y castigo y la necesidad de prevenir estos delitos mediante la educación en un sano compartimiento de la soberanía en el ámbito de las relaciones entre los sexos.

Recibido: 15-10-2018; ACEPTADo: 24-6-2019

51 B. Hernández Pérez, «Alice de Bath o el poder de la palabra». Atlantis, xxiv, 2, 2002, p. 129.

52 T. Whiтtock, A Reading of the Canterbury Tales. Cambridge, CUP, 1968, p. 127: «By his full recognition of her "otherness" he is rewarded by her free acceptance of him. Thus, in the mutual recognition of the other, in each giving only to find that the giving is the taking, in this lies the ideal love-marriage relations». 


\section{REFERENCIAS}

Allen, Peter L., "Reading Chaucer's Good Women». The Chaucer Review, vol. 21, n. ${ }^{4}$ 4, (1987), pp. 19-20.

Annales Paulini, 1307-1341. http://medievalsourcesbibliography.org/sources.php?id=-1084988018.

Beccaria, Cesare, Dei delitti e delle pene (1764). Livorno, Torchi di Glauco Massi, 1833, p. 61.

Bracton, Henry, De legibus et consuetudinibus Anglia, c. 1220-1250. Trad. Samuel E. Thorne. Harvard Bracton Online English and Latin Edition, vol. 2, pp. 414-415.

Braddy, Haldeen, «Chaucer, Alice Perrers, and Cecily Chaumpaigne». Speculum, n. ${ }^{\circ}$ 2, (1977), pp. 906-911.

Cannon, Christopher, "Chaucer and Rape: Uncertainty's Certainties». Studies in the Age of Chaucer, vol. 22, 2000, pp. 67-92; 135-138. Reeditado en «Chaucer's rape: Uncertainties' certainties». E. Robertson y Christine M. Rose (eds.), Representing Rape in Medieval and Early Modern Literature. London, Palgrave, 2001, pp. 256-257.

Cannon, Christopher, «Raptus in the Chaumpaigne Release and a Newly Discovered Document Concerning the Life of Geoffrey Chaucer», Speculum, n. ${ }^{\circ}$ 68, (1993), pp. 74-94.

Capellanus, Andreas, Andrae Capelani regii Francorum de Amore libri tres. Castellón, ed. Amadeo Pages, 1930, p. 120.

Carlson, David R., «The Robberies of Chaucer». English Studies in Canada, vol. 35, n. ${ }^{\circ} 2 / 3$, (2009), pp. 29-54.

Carus, Paul, History of the Devil. New York: Dover Pubs., 2008, p. 325.

Chaucer, Geoffrey, Cuentos de Canterbury. 9. ${ }^{a}$ ed., trad. y ed. P. Guardia Massó. Madrid, Cátedra, 2006, p. 162.

Chaucer, Geoffrey, The Canterbury Tales. Harvard's Geoffrey Chaucer's Website. https://chaucer. fas.harvard.edu/pages/text-and-translations.

Ciceronis, Marco Tullii, Pro Tito Annio Milone ad iudicem oratio (52 a.C.). Lovaina, Apud Vanlinthout et Vendenzendi, 1849, p. 93.

Crow, Martin M. y Virginia E. Leland, "Chaucer's Life», The Riverside Chaucer, Oxford: Oxford University Press, 1987, pp. XI-XxI.

Dean, Trevor, Crime in Medieval Europe 1200-1550. Londres, Routledge, 2001, p. 84.

Dinshaw, Carolyn, Chaucer's Sexual Poetics. Madison, University of Wisconsin Press, 1989, p. 127.

Doherty, Paul, Isabella and the Strange Death of Edward II. Londres, Headline Pubs./Hachette Group, 2013, 262 p.

Dunn, Caroline, "The language of ravishment in Medieval England». Speculum, vol. 86, n. ${ }^{\circ}$ 1, (2011), pp. 79-116.

EDWards, Suzanne, "The rhetoric of rape and the politics of gender in the Wife of Bath's Tale and the 1382 Statute of Rapes». Exemplaria, vol. 23, n. ${ }^{\circ}$ 1, (2011), pp. 3-26.

Ferrini, Contardo, Diritto penale romano. Esposizione storica e dottrinale (1902). Roma, L'Erma di Bretschneider, 1976.

Fortescue, John, De laudibus legum Angliae (1543). On the Laws and Governance of England. Edited by Shelly Lockwood. Cambridge: Cambridge University Press, 1997. 
Froissart, Jean, Chronicles of England, France, and Spain and the adjoining countries, 1326-1400. Trans. by Johnes, Thomas. Londres: Henry G. Bohn, John Street \& Covent Garden, 1857. https://archive.org/details/chroniclesengla00curngoog/page/n10.

Gagarin, Michael, Early Greek Law. Berkeley, University of California Press, 1986.

Greene, Thomas A., «The Jury and the English Law of Homicide, 1200-1600», Michigan Law Review, n. ${ }^{\circ}$ 74, (1976), pp. 413-499.

Harley, Martha P., "Geoffrey Chaucer, Cecilia Chaumpaigne, and Alice Perrers: A Closer Look», Chaucer Review, n. ${ }^{\circ}$ 28, (1993-1994), pp. 78-82.

Holmes, George A., "Judgement on the Younger Despenser, 1326», The English Historical Review, vol. 70, n. ${ }^{\circ} 275$, (1955), pp. 261-267.

IgLEsias-RÁbAde, Luis, «Las penas corporales en el derecho hispánico e inglés en la Edad Media. Estudio comparado", Revista de Estudios Histórico-Jurídicos (Valparaíso), vol. XxxviII, (2016), p. 136.

Kelly, Henry A., "Meanings and Uses of Raptus in Chaucer's Time». Inquisitions and Other Trial Procedures in the Medieval West. Londres, Routledge, 2001, pp. 101-119.

Lacy, Nicola, State Punishment. Political Principles and Community Values. Londres, Routledge, 1988, pp. 16-27.

Langbein, John, Prosecuting crime in the Renaissance: England, Germany and France. Cambridge: Harvard UP, 1974, pp. 118-122.

Mann, Jill, Feminizing Chaucer, Cambridge, D.S. Brewer, 2002.

Martin, George, R.R., A Song of Ice and Fire. Nueva York, Bantam Books, 1996.

Masferrer, Aniceto, "La distinción entre delito y pecado en la tradición penal bajomedieval y moderna. Una propuesta revisionista de la historiografía española, europea y anglosajona». Anuario de Historia del Derecho Español, 87, 2017, pp. 693-756.

Masferrer, Aniceto, Tradición y reformismo en la codificación penal española. Hacia el ocaso de un mito. Materiales, apuntes, reflexiones para un nuevo enfoque metodológico e historiográfico del movimiento codificador europeo. Jaén, Universidad de Jaén, 2003.

Mcnellis, Lindsay, Let Her Be Taken: Sexual Violence In Medieval England. Orlando, University of Central Florida, 2008, pp. 4-5.

Morrison, Susan S., «The Use of Biography in Medieval Literary Criticism: The Case of Geoffrey Chaucer and Cecily Chaumpaigne», The Chaucer Review, vol. 34, n. ${ }^{\circ}$ 1, 1999, pp. 69-86.

Mortimer, Ian, The Greatest Traitor: The Life of Sir Roger Mortimer, Ruler of England: 1327-1330. Londres: Macmillan, 2013.

ONU, Marco de Análisis para la Prevención de Crimenes Atroces, 2014; reimp. 2018. http://www.un.org/ en/genocideprevention/documents/publications-and-resources/Genocide_Framework\%20 of\%20Analysis-Spanish.pdf.

Pallotti, Donatella, «A Most Detestable Crime'. Representations of Rape in the Popular Press of Early Modern England». LEA-Lingue e Letterature d'Oriente e d'Occidente, vol. 1, n. ${ }^{\circ}$, 2012, pp. 287-290.

Pearsall, Derek, The Life of Geoffrey Chaucer: a Critical Biography. Oxford, Blackwell, 1992, pp. 135-138. 
Picardo Reyes, Miguel Ángel, Anatomía de la Tortura. Protocolo para la Documentación Psicosocial de la Tortura en el marco del Sistema Interamericano de Derechos Humanos. PDPT-SIDH. Iztapalapa: Universidad Autónoma Metropolitana de Méjico, 2003.

Pluknett, Theodor F.T., "Chaucer's Escapade». The Law Quarterly Review, 64, 1948, pp. 33-79.

Powell Harley, Martha, «Geoffrey Chaucer, Cecilia Chaumpaigne, and Alice Perrers: A Closer Look», Chaucer Review, 28, 1993-94, pp. 78-82.

Pugh, Tison, «Chaucer's Rape, Southern Racism, and the Pedagogical Ethics of Authorial Malfeasance», College English, vol. 67, n. ${ }^{\circ}$ 6, 2005, pp. 569-586.

Ramos VÁzQuez, I., «La represión de los delitos atroces en el Derecho Castellano de la Edad Moderna». Revista de estudios histórico-juridicos, n. ${ }^{\circ}$ 6, 2004, pp. 255-299.

Robertson, Elizabeth, «Raptus and poetic married love in Chaucer's Wife of Bath's Tale and James I's Kings Quair». Reading Medieval Culture. Ed. Robert M. Stein and Sandra Pierson Prior. Notre Dame, University of Notre Dame Press, 2005, pp. 302-313.

Robinson, Olivia F., The Criminal Law of Ancient Rome. Baltimore: John Hopkins UP, 2001.

Rodríguez SÁnchez, Ángel, «La soga y el fuego. La pena de muerte en España siglos XVi y xviı». Cuadernos de Historia Moderna de la Universidad Complutense, n. ${ }^{\circ} 15,1994$, pp. 13-39.

Rose, Christine M., «Reading Chaucer Reading Rape». Representing Rape in Medieval and Early Modern Literature, ed. Elizabeth Robertson and Christine M. Rose, Nueva York, Palgrave, 2001, pp. 21-60.

Saunders, Corinne, Rape and Ravishment in the Literature of Medieval England. Woodbridge, Boydel \& Brewer, 2001, p. 72.

Shopland, Norena, "The man with the upside-down arms", capítulo de Forbidden Lives LGTB. Histories from Wales. Bridgen, Seren Books, 2017, pp. 28-37.

Sidhu, Nicole N., Indecent Exposure. Gender, Politics and Obscene Comedy in Middle English Literature. Filadelfia, University of Pennsylvania Press, 2016, pp. 76-112.

Sobecki, Sebastian, «Wards and Widows: Troilus and Criseyde and New Documents on Chaucer's Life». ELH, Johns Hopkins University Press, vol. 86, n. ${ }^{2}$, Summer 2019, pp. 413-440.

Sponsler, Clare, "The King's Boyfriend. Froissart's Political Theater of 1326», en G. Burger y S.F. Kruger, (eds.), Queering the Middle Ages, Medieval Cultures Series, 27, April, 2001, Minneapolis, University of Minnesota Press.

Statute of Westminster, The First, 1275 c. 5 (Regnal. 3_Edw_1). http://www.legislation.gov. uk/aep/Edw1/3/5/contents.

Statute of Westminster, The Second (De Donis Conditionalibus) 1285, c. 1 (Regnal. 13_Edw_1). http://www.legislation.gov.uk/aep/Edw1/13/1.

Stearns, A. Warren, «Evolution of punishment». Journal of Criminal Law and Criminology, vol. 27, n. ${ }^{\circ} 2,1936$, pp. 219-223.

WARner, Kathryn, «The Charges Against Hugh Despenser The Younger, November 1326»: http:// edwardthesecond.blogspot.com/2009/04/charges-against-hugh-despenser-younger.html.

WARner, Kathryn, Edward II and Hugh Despenser the Younger: Downfall of a King's Favourite. Barnsley, Pen \& Sword, 2018.

Watts, P.R., «The Strange Case of Geoffrey Chaucer and Cecilia Chaumpaigne». Law Quarterly Review, 63, 1947, pp. 491-513. 
Westerhof, Danielle, «Deconstructing identities on the scaffold: the execution of Hugh Despenser the Younger, 1326", Journal of Medieval History, vol. 33, n. ${ }^{\circ}$ 1, 2017, pp. 87-106.

Wнiттоск, Thomas, A Reading of the Canterbury Tales. Cambridge: CUP, 1968. 